\title{
Managerial Optimism, Investment Efficiency, and Firm Valuation
}

\author{
I-Ju Chen* \\ Yuan Ze University, Taiwan \\ Shin-Hung Lin \\ Yuan Ze University, Taiwan
}

This study investigates the relationship between managerial optimism, investment efficiency, and firm valuation. This study follows the Campbell's measurement for managerial optimism and investigates the influences of the different levels of managerial optimism on improving investment efficiency and firm value when firms tend to under-invest or over-invest. The results indicate that an under-invested firm with a CEO who has a higher level of managerial optimism can improve the firm's investment efficiency by reducing the degree of underinvestment, which further increases the firm's value. However, when firms tend to overinvest, there is insufficient evidence to show that a firm with a lower level of CEO managerial optimism will effectively improve the firm's investment efficiency and increase firm value by reducing the degree of overinvestment. The results generated in this study help scholars and practitioners understand how managerial optimism affects the investment efficiency of firms. (JEL: G02, G30)

Keywords: managerial optimism, investment efficiency, overinvestment, underinvestment

\section{Introduction}

The behavioral finance literature suggests that people make systematic

* I-Ju Chen acknowledges the partial financial support of the National Science Council of Taiwan (NSC). The authors are also grateful for the feedback from an anonymous referee, Editor-in-Charge Hersh Shefrin, and Editor-in-Chief Panayiotis Theodossiou. Previous version of this paper has been presented at the 2nd Annual International Conference on Accounting and Finance (Singapore, 2012).

(Multinational Finance Journal, 2013, vol. 17, no. 3/4, pp. 295-340)

(C) Multinational Finance Society, a nonprofit corporation. All rights reserved. DOI: $10.17578 / 17-3 / 4-6$ 
errors in the way that they think. They may be optimistic or overconfident about the outcomes of decisions. Optimism means that individuals systematically overestimate the future outcome of an event (Heaton, 2002, Lin et al., 2005, Barros and Silveira, 2009, Shefrin, 2001). Overconfidence, similar to optimism, means that individuals overestimate their personal ability and thus put too much weight on their personal information or viewpoint (Barros and Silveira, 2009; Malmendier and Tate, 2005a; Hirshleifer et al., 2012). Either way, their preferences may create distortions. Though these individual behavioral preferences, documented in many studies, affect asset pricing in the stock market (Barberis, Shlerifer, and Vishny, 1998; Daniel, David, and Subrahmanyam, 1998; Barberis and Thaler, 2003), only a handful of studies, Malmendier and Tate (2005a, b), Ben-David, Graham, and Harvey (2011), and Hirshleifer, Teoh, and Low (2012), investigate how these individual biases affect corporate investment decisions and investment efficiency.

Malmendier and Tate (2005a, b) develop measures of CEO optimism and empirically confirm that the investment distortions of firms are associated with managerial personal attributes or behavioral biases. Ben-David, Graham, and Harvey (2011) compute the magnitude of CFO miscalibration about future stock market return as the measure of overconfidence and conclude that top executives miscalibrate and that their miscalibrations significantly affect the investment behavior of their firms. Hirshleifer, Teoh, and Low (2012) using options- and press-based proxies for CEO overconfidence, further document that firms with overconfident CEOs invest more in innovation activities and achieve greater innovative success for given research and development expenditures. Making investment decisions is an integral and vital part of managing a firm. An efficient investment decision may be expected to enhance firm valuation. Although previous studies provide evidence that corporate investment is affected by managerial personal preference or behavior biases, these studies do not further address how managerial optimism affects a firm's investment efficiency, or whether managerial optimism helps to improve corporate investment efficiency and its association with firm valuation. Our study aims to fill this gap.

We hypothesize that an under-invested firm with a higher level of managerial optimism tends to invest more, given that an optimistic manager is usually willing to invest more (Glaser et al. 2008). If this is the case, then we will observe that an under-invested firm with a higher level of managerial optimism will have higher capital investment, 
enhancing the firm's investment efficiency. We follow the research of Campbell et al. (2011), which extends the work of Malmendier and Tate (2005), and develop a measure of CEO optimism. We also follow Biddle et al. (2009), using an aggregated measure of ex-ante characteristics of a firm's cash and leverage ratios, to classify the underand over- investment level of sample firms.

The main findings are summarized as follows: First, based on our optimism measurement, we find almost $40 \%$ of CEOs are optimistic in our sample, which is consistent with the prior studies (e.g., Campbell et al., 2011). In addition, a firm with a highly optimistic CEO will invest more than firms whose CEOs have lower levels of optimism; this finding remains after implementing many robustness checks. Last, our findings indicate that an under-invested firm with a CEO that has a higher level of managerial optimism improves the firm's investment efficiency by reducing the amount of underinvestment, thereby increasing firm value. This is consistent with our hypotheses. However, our results do not provide sufficient evidence to support the other hypothesis when firms over-invest. That is, for an over-invested firm, a CEO with a lower level of managerial optimism does not appear to effectively improve the firm's investment efficiency and further increase firm value by reducing the level of overinvestment. We also investigate how CEO optimism affects investment decisions for firms under financial constraints. We find that optimistic CEOs in financially-constrained firms are still willing to increase their capital expenditure, also leading to increases in firm valuation.

Our study contributes to the literature that firms with a higher level of managerial optimism help to improve firm investment efficiency, especially when these firms are under-invested. Our study also complements the research in behavioral finance showing that corporate investment policy is affected by managerial psychological biases which might improve firm efficiency when firms do not have enough capital investment. Several studies are also related to our research. Heaton (2002) is the first study to examine whether managerial optimism affects corporate investment decisions. They find that an optimistic manager may avoid negative net present value projects which must be financed externally yet be more willing to undertake risky projects if they are loyal to shareholders and have the funds to do so. Campbell et al. (2011) find that CEO turnover is related to the level of CEO optimism. Boards terminate low-optimism and high-optimism CEOs more frequently than moderately-optimistic CEOs. They interpret this 
result as evidence that a moderate level of CEO optimism is more likely to choose a first-best investment level. Their findings provide further justification for our efforts to explore how CEO optimism affects firm investment efficiency and firm value.

The remainder of this study is organized as follows: section II summarizes the literature and proposes the hypotheses statements; section III describes the data and variables; section IV discusses the empirical methodology; section $\mathrm{V}$ presents the main empirical analyses and results; and section VI concludes.

\section{Literature Review and Hypotheses Development}

The major issue in this study is how managers with different levels of optimism affect the investment efficiency of their firms, and what the effect is for firms that are prone to under- or over-invest. To explore these ideas and develop our hypotheses, we summarize the literature below.

Researchers generally find that an optimistic manager is likely to believe and overestimate the probability that a good thing will happen, but underestimate the probability that a bad thing will happen (Heaton, 2002; Lin et al., 2005; Barros and Silveira, 2009; Shefrin, 2001; Glaser, 2008). The managerial optimism tendency of systematically overestimating the future average cash flow of a firm is related to corporate policies regarding decisions such as investments, financing, dividend payouts, or acquisitions, and results in managerial decisions with a certain degree of irrationality.

Heaton (2002) find that optimistic managers prefer internal financing to external financing because they believe market investors underestimate the value of their firm and thus hesitate to raise funds from the financial markets. Several empirical studies, such as Lin et al. (2008) and Hackbarth (2008), confirm this theoretical prediction by Heaton (2002) and show that managerial optimism can explain pecking order preferences in financial decisions. Barros and Silveira (2009) further show that firms with optimistic managers will choose a more aggressive financing policy, resulting in firms that have higher leverage ratios, affecting their capital structure.

Managerial behavior tendencies may not only affect a firm's financing decisions but also impact its investment decisions. Jensen (1986), using the concept of agency cost of free cash flow, predicts that 
managers may invest in negative NPV projects due to self-interest. This agency cost between managers and shareholders may thus cause overinvestment, resulting in investment distortions. Myers and Majluf (1984) posit that the existence of information asymmetry between a firm's managers and outsiders will cause distorted investments, thus reducing the efficiency of capital investments.

The above studies, though they explore whether a firm's investment decision is associated with managerial attitudes, do not specifically investigate whether the investment distortion is affected by managerial psychological preferences, such as optimism. Malmendier and Tate (2005a) is the first study to consider managerial optimism in corporate investment decisions. They measure the timing of CEO's stock option exercise as the proxy for CEO optimism and find that overoptimistic CEOs are significantly more responsible for the firm's cash flow. By hand-collecting data on how the press portrays each CEO as the measure of managerial optimism, Malmendier and Tate (2005b) reconfirm their findings that managerial overoptimism accounts for corporate investment distortions. Using a unique database of German companies to proxy for managerial optimism, Glaser et al.(2008) show that the investment-cash flow sensitivity is higher for firms with optimistic managers, which again supports the findings of Malmendier and Tate (2005a, b). Malmendier and Tate (2008) further find that a highly optimistic CEO does not necessarily predict an acquisition decision, but that firms with highly optimistic CEOS and plentiful internal cash flow tend to make lower-quality acquisitions. This implies that optimistic managers may cause a firm to invest more than a firm with less optimistic managers, thereby exposing the firm to risk (Glaser et al., 2008; Malmendier and Tate, 2008).

A distorted investment, such as an over- or under-investment, may reduce the investment efficiency of a firm (Biddle et al., 2009). Minimizing the investment distortion helps improve investment efficiency. In a perfect market all projects with positive net present value should be funded, thus enhancing firm valuation. Therefore, implementing a positive NPV project enhances investment efficiency (Stein, 2003). However, in the real world in which investors do not have same information as corporate managers, investment efficiency may be distorted either by limiting firms' ability to finance a potential project (Hubbard, 1998; Bertrand and Mullainathan, 2003) or by inferior project selections, diversion of funds to perquisites, or even expropriation of resources by managers (Stein, 2003). 
Several papers investigate how to improve investment efficiency in the context of market imperfection. Biddle and Hilary (2006) and Biddle et al. (2009) show that either improvement in accounting quality or reporting quality aids in alleviating information asymmetries that reduce both over- and under- investment possibility. However, no financial study to date directly examines how to improve investment efficiency, with the exception of studies of accounting approaches. This study seeks to understand whether managerial optimism affects the investment efficiency of a firm and in what circumstances managerial optimism minimizes investment distortion.

Studies indicate that managers with higher level of optimism are more sensitive to cash flows and may forgo positive net present value projects if internal funds are insufficient. Meanwhile, research also suggests that managers with a certain degree of optimism tend to undertake riskier projects because they overestimate the future payoff, meaning that they increase investment (Heaton, 2002; Barros and Silveira, 2009; Shefrin, 2001; Goel and Thakor, 2008). Based on the above analyses, we predict that an optimistic CEO of a firm with plenty of cash flow (under-investing) will be less concerned about costly external financing and thus more willing to undertake a risky project expected to have higher returns. On the other hand, an over-invested firm with a less optimistic CEO should follow more conservative investment policies, resulting in decreased capital expenditure. Thus, we propose the first hypothesis:

$H 1_{a}$ : A firm with a high possibility of underinvestment and whose CEO is highly optimistic will invest more than a similar firm whose CEO has a low level of optimism.

$H 1_{b}$ : A firm with a high possibility of overinvestment and whose CEO has a low level of optimism will invest less than a similar firm whose CEO is highly optimistic.

When a distorted investment may reduce the investment efficiency of a firm, managerial sentiment may thus impact a firm's value. Gervais et al. (2002) is the first paper to provide a theory showing that moderately optimistic managers are more likely to take on risky investment projects which are in the best interest of shareholders than rational managers. Goel and Thakor (2008) explain theoretically the reason that a CEO with moderate overoptimism helps diminish 
underinvestment inefficiency. This is because an overoptimistic CEO may overestimate the probability of a high payoff and thus be more willing to bear risks in accepting projects. Because an overoptimistic $\mathrm{CEO}$ is more willing to invest in projects with low probabilities of high payoff, this may improve investment efficiency for an underinvested firm, enhancing shareholders' wealth. Campbell et al. (2011) follows a logic similar to that of Gervais et al. (2002) and Goel and Thakor (2008) and finds that CEOs with relatively moderate optimism help maximize firm valuation. Based on the above analyses, we predict that managerial optimism is associated with firm investment efficiency and firm valuation. Thus, we propose the second hypothesis:

$H 2_{a}$ : The value of a firm with a high possibility for underinvestment and whose CEO is highly optimistic will be greater than that of a similar firm whose CEO has a low level of optimism.

$H 2_{b}$ : The value of a firm with a high possibility for overinvestment and whose CEO has a low level of optimism will be greater than that of a similar firm whose CEO is highly optimistic.

\section{Data and Variables}

\section{A. Sample and Data}

The variable of interest is CEO optimism and the main dependent variables include investment (Invest) and Firm value (Value). To measure CEO optimism, we rely on the data collected from ExecuComp database which provides information about CEO compensation in terms of salary, bonus, and stock options granted from 1992 to 2009. Investment is measured by the sum of research and development expenditure, capital expenditures, and acquisition expenditure minus cash receipts from sales of property, plant, and equipment, then divided by lagged total assets (Biddle et al., 2009). Firm value is defined as Tobin's Q. Tobin's Q is sum of market value of equity plus total assets minus book value of equity divided by total asset (Baker et al., 2003).

We collect the data on ownership structure from the Compact D/SEC database, Thomson Reuters, and the Corporate Library. The measure provided by Gompers et al. (2003) is used as a proxy for external governance. A higher score indicates a higher level of 
TABLE 1. Definitions of Variables Used in this Study

\begin{tabular}{|c|c|}
\hline Variable & Definition \\
\hline \multicolumn{2}{|l|}{ A. Dependent Variables } \\
\hline Investment (Invest) & $\begin{array}{l}\text { The sum of research and development expenditure, capital } \\
\text { expenditures, and acquisition expenditure less cash } \\
\text { receipts from sales of property, plant, and equipment and } \\
\text { divided by lagged total assets. }\end{array}$ \\
\hline Capital Investment (Ic) & $\begin{array}{l}\text { Capital expenditures divided by lagged sales of property, } \\
\text { plant, and equipment. }\end{array}$ \\
\hline Noncapital Investment (In) & $\begin{array}{l}\text { The sum of research and development expenditure and } \\
\text { acquisition expenditure and divided by lagged total assets. }\end{array}$ \\
\hline Firm value (Value) & $\begin{array}{l}\text { Market value of equity plus total assets minus book value } \\
\text { of equity divided by total assets. Book equity is calculated } \\
\text { as total assets minus total liabilities minus preferred stock } \\
\text { liquidating value plus deferred taxes and investment tax } \\
\text { credit. (Tobin's Q, following Baker, Stein and Wurgler, } \\
\text { 2003, and Malmendier and Tate, 2005a). }\end{array}$ \\
\hline \multicolumn{2}{|l|}{ B. Measures of Optimism } \\
\hline $\begin{array}{l}\text { High-optimism CEO } \\
\text { indicator }(\mathrm{HighOpti})\end{array}$ & $\begin{array}{l}\text { An indicator variable that equals } 1 \text { for all years if the CEO } \\
\text { exercises stock options at (or more than) } 100 \% \text { moneyness } \\
\text { at least twice for the studied period, and } 0 \text { otherwise. }\end{array}$ \\
\hline $\begin{array}{l}\text { Low-optimism CEO } \\
\text { indicator (LowOpti) }\end{array}$ & $\begin{array}{l}\text { An indicator variable that equals } 1 \text { for all years if the CEO } \\
\text { exercises stock options at (or less than) } 30 \% \text { moneyness at } \\
\text { least twice for the studied period, and } 0 \text { otherwise. }\end{array}$ \\
\hline \multicolumn{2}{|l|}{ C. Investment Variables } \\
\hline OverInvest & $\begin{array}{l}\text { We first rank firms into quartiles based on their cash } \\
\text { balance and adjusted leverage (we multiply adjusted } \\
\text { leverage by minus one before ranking). An observation is } \\
\text { classified as an overinvestment firm (OverInvest) when the } \\
\text { average value is in the top quartiles. }\end{array}$ \\
\hline UnderInvest & $\begin{array}{l}\text { Following the above calculation, an observation is } \\
\text { classified as an underinvestment firm (UnderInvest) when } \\
\text { the average value is in the bottom quartiles. }\end{array}$ \\
\hline Cash ratio & $\begin{array}{l}\text { The ratio of cash divided by total assets; firms with more } \\
\text { cash may tend to over-invest. }\end{array}$ \\
\hline Leverage & $\begin{array}{l}\text { The ratio of long-term debt divided by the sum of } \\
\text { long-term debt and the market value of equity; firms with } \\
\text { more leverage or debt may tend to under-invest. }\end{array}$ \\
\hline Ind. leverage & $\begin{array}{l}\text { The mean ratio of firms in the same industry for each year. } \\
\text { The industry is defined based on Fama \& French } \\
\text { 49-industry classification, provided there are at least } \\
\text { twenty firms in one industry. }\end{array}$ \\
\hline
\end{tabular}


TABLE 1. (Continued)

\begin{tabular}{|c|c|}
\hline Variable & Definition \\
\hline \multicolumn{2}{|c|}{ D. Other Independent Variables } \\
\hline Firm size & $\begin{array}{l}\text { Natural log of book total assets; used to measure the size } \\
\text { of a firm. }\end{array}$ \\
\hline$M / B$ & $\begin{array}{l}\text { Market value of equity divided by book value of equity; } \\
\text { used to measure the growth opportunity of a firm. }\end{array}$ \\
\hline CF/sale & $\begin{array}{l}\text { The ratio of operating income before depreciation to sales; } \\
\text { used to measure the asset management efficiency of a firm. }\end{array}$ \\
\hline Slack & $\begin{array}{l}\text { The ratio of cash to total property, plant, and equipment; } \\
\text { used to measure the financial slack of a firm. }\end{array}$ \\
\hline Operating Cycle & $\begin{array}{l}\text { The log of receivables to sales plus inventory to cost of } \\
\text { goods sold multiplied by 360; used to measure the } \\
\text { operating cycle of a firm. }\end{array}$ \\
\hline Capx/sale & The ratio of capital expenditures to sales. \\
\hline Profitability & $\begin{array}{l}\text { The ratio of operating income before depreciation to total } \\
\text { assets. }\end{array}$ \\
\hline Return & Cumulative monthly stock returns over past 12 months. \\
\hline Dividend & $\begin{array}{l}\text { An indicator variable that equals } 1 \text { if the firm paid a } \\
\text { dividend that year, and } 0 \text { otherwise. }\end{array}$ \\
\hline CEO ownership & The fraction of outstanding shares held by the CEO. \\
\hline CEO-equity-based pay & $\begin{array}{l}\text { The percentage of equity-based compensation (stock } \\
\text { option and restricted stock grants) in a CEO's total } \\
\text { compensation. }\end{array}$ \\
\hline GIM index & $\begin{array}{l}\text { Taken from Gompers et al. (2003), based on } 24 \\
\text { antitakeover provisions as the proxy for antitakeover } \\
\text { provisions. Higher index levels correspond to more } \\
\text { managerial power. }\end{array}$ \\
\hline Pension Own & $\begin{array}{l}\text { The fraction of outstanding shares held by the } 18 \text { largest } \\
\text { public pension funds (as in Cremers and Nair, 2005). }\end{array}$ \\
\hline Analysts & The number of analysts following the firm. \\
\hline most_constrained & $\begin{array}{l}\text { An indicator variable that equals } 1 \text { for all years if firms are } \\
\text { within the highest } 30 \% \text { of Kaplan-Zingales index, and } 0 \\
\text { otherwise; we calculate the Kaplan-Zingales index based } \\
\text { on the work of Kaplan and Zingales (1997). }\end{array}$ \\
\hline least_constrained & $\begin{array}{l}\text { An indicator variable that equals } 1 \text { for all years if firms are } \\
\text { within the lowest } 30 \% \text { of Kaplan-Zingales index, and } 0 \\
\text { otherwise. }\end{array}$ \\
\hline
\end{tabular}


anti-takeover provisions imposed, implying that shareholders' rights in those firms is weaker. The number of analysts following is collected from the $\mathrm{I} / \mathrm{B} / \mathrm{E} / \mathrm{S}$ database.

Accounting data is collected from Compustat database. We delete firm-year observations that have missing data related to our dependent variables, independent variables and any of our optimism measures. We further exclude firms in the utilities industry (SIC codes 4900-4999) and firms in financial industries (SIC codes between 6000 and 6999) due to their special capital structure and investment characteristics. All variables used in this study are defined in table 1 .

\section{B. The Measurement of Managerial Optimism}

As mentioned, previous studies have applied a variety of proxies for managerial optimism as this phenomenon of managerial bias is not only difficult to directly observe but also difficult to measure (Malmendier and Tate, 2005a, b; Campbell et al., 2011). We follow Campbell et al. (2011) and apply optimism measures based on stock option holdings and exercise data constructed from ExecuComp database. Campbell et al. (2011) classify CEO optimism measure into three levels of low, moderate, and high. This allows us to investigate the relationship between different levels of managerial optimism and investment efficiency (or firm value). For each CEO-firm-year, we first calculate the realizable value per option as the exercisable option's total realizable value (OPT_UNEX_EXER_EST_VAL) divided by the number of exercisable options (OPT_UNEX_EXER_NUM) held by the CEO. We then use the stock price at the fiscal year end (PRCCF) to minus the realizable value per option to get the estimated average exercise price. Finally, we use the realizable value per option divided by the estimated average exercise price and obtain the average percent moneyness. CEOs who hold stock options more than $100 \%$ deep in the money are identified as highly optimistic.

In terms of the low- and moderate-optimism measures (indicators of CEOs with a lower or moderate level of optimism, respectively) we estimate the average percent moneyness of the exercised options. For each CEO-firm-year observation, we first calculate the per option realized exercise value as the exercising option's total realized value (OPT_EXER_VAL) divided by the exercised option's number (OPT EXER_NUM) held by the CEO. We then use the stock price at the fiscal year end (PRCCF) and deduct per option realized exercise value to obtain the estimated average exercise price of exercised options. 
Finally, we use the per option realized exercise value and divide it by the estimated average exercise price of exercised options to obtain the average percentage moneyness of exercised options. When a CEO's exercised stock options are less than $30 \%$ in the money and the CEO does not hold other exercisable options that are more than $30 \%$ in the money, the CEO is identified as having a low level of optimism. Furthermore, when a CEO holds and/or exercises options with average percentage moneyness between $30 \%$ and $100 \%$ the CEO is identified as being moderately optimistic.

We begin with 29,829 CEO-year observations from 1992 to 2009 from the Compustat Execucomp database. The sample size decreases to 23,683 after the financial industry (2-digit SIC=60-69) and utilities (2-digit SIC code=49) are excluded. We further only include those CEOs who have the option granted, reducing the sample to 16,285. Finally we are left with 7,890 CEO-year observations when the sample must have the valid realizable value and realized exercise value per option. Similar to Campbell et al. (2011), we require that CEOs show the relevant exercise behavior at least twice in the sample period and classify them as high/low optimism beginning with the first time they do.

\section{The Measurement of Over- and Underinvestment}

Although firms might deviate their optimal investment ratio due to the defects of market imperfection, the measure of such deviation is conceptually and empirically difficult. In this paper, we postulate that certain firm-specific characteristics are likely to affect the possibility of firms to over- or under-invest. Several studies indicate that a higher cash ratio increases the possibility of managers deciding to make inefficient investments (Jensen, 1986; Opler et al., 1999; Stein, 2003). By the same token, firms with higher leverage ratio may suffer more severe problems of bankruptcy or debt overhang, forcing them to under-invest (Myers, 1977, 1984; Stein, 2003). Since the cash balance and leverage ratio may affect firm's investment level, we adopt the method used by Biddle et al. (2009) and use these two variables to proxy for over- and underinvestment. We first multiply leverage by -1 so that it resembles cash in that when it increases the tendency is towards overinvestment. We then rank the firms into deciles by each of these two variables for each year. Because the general leverage level across industries may vary over time, we also consider industry effects across the sample period (Lang 
et al., 1996) and rank firms within the industry. ${ }^{1}$ Next we re-scale this to a range of 0 to 1 . Based on the average ranked value of cash and leverage, we can obtain a composite score measure which is computed as the average of the ranked values of the two variables. ${ }^{2}$ We further define two dummy variables: OverInvest (representing firms that are more prone to over-invest) when the composite score is near 1 (the top $25 \%$ of the sample firm), and UnderInvest (representing firms that are more prone to under-invest) when the composite score is near 0 (the lowest $25 \%$ of the sample firm).

\section{Methodology}

\section{A. Difference Test}

To test the hypotheses, we first classify all sample firms into two subsamples: firms prone to under-invest and firms prone to over-invest, based on their ex-ante characteristics of firm cash balance and firm leverage. We then conduct a difference test on each of these subsamples, comparing investment ratio and firm value between highand low-optimism CEOs. We predict that the average investment or firm value of firms with highly optimistic CEOs will significantly be higher than those of firms with CEOs low in optimism.

\section{B. Regression Specifications}

We further apply multiple panel regressions to test the relation between investment and CEO optimism when firms are more prone to under- or over-invest in the overall sample. The estimated models are:

$$
\begin{aligned}
\text { Invest }_{i t}= & \alpha_{0}+\alpha_{1} \text { HighOpti }_{i t}+\alpha_{2} \text { UnderInvest }_{i t}+\alpha_{3} \text { HighOpti }_{i t} * \\
& \text { UnderInvest }_{i t}+\sum \text { Controls }_{i t}+\varepsilon_{i t}
\end{aligned}
$$

1. We followed the method of Fama and French (1997) in classifying industries. Currently, they classify industry into 49 categories. We are grateful to them for making this data accessible on their website:

http://mba.tuck.dartmouth.edu/pages/faculty/ken.french/data_library.html.

2. The average is taken in order to help reduce the measurement error in our variables. 


$$
\begin{aligned}
\text { Invest }_{i t}= & \beta_{0}+\beta_{1} \text { LowOpti }_{i t}+\beta_{2} \text { OverInvest }_{i t}+\beta_{3} \text { LowOpti }_{i t} * \\
& \text { OverInvest }_{i t}+\sum \text { Controls }_{i t}+\varepsilon_{i t}
\end{aligned}
$$

where Invest is the investment ratio, our main dependent variable, measured by capital expenditures divided by lagged total assets. HighOpti is the high-optimism CEO indicator, which is 1 if CEOs are classified as having a high level of optimism and 0 otherwise. LowOpti is the low-optimism CEO indicator, which is 1 if CEOs are classified as having a low level of optimism and 0 otherwise. OverInvest and UnderInvest are respectively used to classify firms as being more prone to over- or under-invest as described in section III, $C$. We use the OLS method to estimate Models (1a) and (1b). We adjust the standard errors for heteroskedasticity, serial-, and cross-sectional correlation using a one dimensional cluster at the firm level (Petersen, 2009). We also include industry and year fixed-effects in the regression specifications. 49-industry classification provided by Fama and French (1997) is used to control the industry shocks to the investment.

These control variables include financial variables, such as firm size, market to book ratio, industry leverage, operating cash flow to sales, slack, operating cycle, dividend, past one-year stock return, and other governance variables, including CEO ownership, CEO-equity-based pay, institutional ownership, analyst following, and Gomper et al. (2003) index (Amihud and Lev, 1981; Biddle et al., 2009; Glaser et al., 2008; Heaton, 2002; Hubbard, 1998; Jensen, 1986, 1993; Lin et al., 2005; Malmendier and Tate, 2005a, b; Shleifer and Vishny, 1989). Previous studies indicated that the level of investment depends on the cash flow sensitivity and growth opportunities (Hubbard, 1998; Heaton, 2002; Lin et al., 2005; Malmendier and Tate, 2005a, b). Firms may forgo positive net present value projects if they do not have sufficient internal funds. They tend to increase investment if they see plentiful growth opportunities. Therefore we control for the effect of internal funding and growth opportunities on investment. The operating cash flow to sales, operating cycle, the level of slack, and dividend are used to proxy for internal funding. A higher level of firm leverage more easily induces the problem of debt-overhang and leads to underinvestment (Myers, 1977, 1984; Stein, 2003), therefore we control for the leverage effect in the regression. Lamont (2000) argues that changes in the discount rate will affect the level of investment. Their 
empirical evidence finds that investment is positively associated with stock return. Therefore, we control for past stock returns in the regression. Agency conflicts between managers and shareholders have been documented to have a significant impact on the optimal investment of firms. The empire building tendency or entrenchment behaviors of managers may lead firms to deviate from their optimal investment choices, affecting investment level (Amihud and Lev, 1981; Biddle et al., 2009; Jensen, 1986, 1993; Shleifer and Vishny, 1989). Therefore, we also include governance variables in the regression as the controls.

Our first hypothesis states that different levels of CEO optimism will reduce under- and over-investment when firms are more prone to underor over-invest. Thus we use Model (1a) to test $H 1_{a}$ by estimating whether the coefficient $\alpha_{3}$ is larger than zero, and we use Model (1b) to test $H 1_{b}$ by estimating whether the coefficient $\beta_{3}$ is smaller than zero. $\left(H 1_{a}: \alpha_{3}>0\right.$ when firms are prone to under-invest; $H 1_{b}: \beta_{3}<0$ when firms are prone to over-invest.)

To test the relation between firm value and CEO optimism when firms are more prone to over- or under-invest, we use models similar to those presented above, but the dependent variable is firm value, which is represented by Tobin's Q. Thus the estimated models are:

$$
\begin{gathered}
\text { Value }_{i t}=\delta_{0}+\delta_{1} \text { HighOpti }_{i t}+\delta_{2} \text { UnderInvest }_{i t}+\delta_{3} \text { Ho }_{i t} * \\
\text { UnderInvest }_{i t}+\sum \text { Controls }_{i t}+\varepsilon_{i t} \\
\text { Value }_{i t}=\lambda_{0}+\lambda_{1} \text { LowOpti }_{i t}+\lambda_{2} \text { OverInvest }_{i t}+\lambda_{3} \text { LowOpti }_{i t} * \\
\text { OverInvest }_{i t}+\sum \text { Controls }_{i t}+\varepsilon_{i t}
\end{gathered}
$$

where Value is the firm value measured by Tobin's Q.

According to our second hypothesis, CEO optimism contributes to the value of a firm when firms are classified as more prone to over- or under-invest. We use Model (2a) to test $H 2_{a}$ by estimating whether the coefficient $\delta_{3}$ is larger than zero, and we use Model (2b) to test $H 2_{b}$ by estimating whether the coefficient $\lambda_{3}$ is larger than zero $\left(H 2_{a}: \delta_{3}>0\right.$ when firms are prone to under-invest; $H 2_{b}: \lambda_{3}>0$ when firms are prone to over-invest.). We also control the governance variables and other financial variables such as firm size, the level of capital expenditure 
(Capex/size), Profitability, and Leverage which have been shown to be significantly related to firm performance in the literature (Lemmon and Lins, 2003; Baek, et al., 2004).

\section{Empirical Analysis}

\section{A. Summary Statistics}

Table 2 presents the summary statistics of CEOs with different levels of optimism. Panel A of table 2 presents the distribution of CEO optimism across two different sample periods. We first test whether the distribution of CEO optimism is similar to that of Campbell et al. (2011). We find that $37.61 \%$ of the CEOs have a high level of optimism and $10.23 \%$ of the CEOs have a low level of optimism for the period 1992 to 2005. The distribution of CEO optimism is close to that of Campbell et al. (2011).

Panel B of table 2 extends our analysis from 1992 to 2009 based on CEO-firm-year data. The total number of CEOs and the proportion of high- and low-optimism CEOs are presented by year. For the entire sample period, the average proportion of high- and low-optimism CEOs are $39.75 \%$ and $10.22 \%$, respectively. Overall, the proportion of high-optimism CEOs is greater than the proportion of low-optimism CEOs every year, consistent with the findings of Malmendier and Tate (2005a) and Glaser et al. (2008). We also find that the proportion of high-optimism CEOs decreases in 2009, while the proportion of low-optimism CEOs increases in 2009. This dramatic increase in low-optimism CEOs for those two years may be due to the effect of the financial crisis. During economic downturns or dramatic economic instability, managers become more uncertain about the future and thus less likely overestimate the payoff of a portfolio. Therefore we observe that the proportion of low-optimism CEOs increases after 2008. Similar reasoning can be applied to the observed patterns in 2001 and 2002, as many financial scandals happened which affected attitudes toward expected payoffs of investment projects.

Table 3 shows the summary statistics of the firm data and Pearson correlation for all variables from 1992 to 2009. All variables are winsorized at the 5th and 95th percentiles to reduce the influence of outliers. The mean (median) of our main dependent variables, investment and firm value, are 17.09\% (12.39\%) and 2.42 (1.92), 
TABLE 2. Sample Distribution by CEO and CEO-Year Observations

\begin{tabular}{|c|c|c|c|}
\hline \multirow[b]{2}{*}{ Year(s) } & \multicolumn{3}{|c|}{ CEOs } \\
\hline & $\mathrm{N}$ & Low Optimism & High Optimism \\
\hline \multicolumn{4}{|c|}{ A. Distributions by CEO } \\
\hline $1992-2005$ & 1534 & $10.23 \%$ & $37.61 \%$ \\
\hline 1992-2009 & 1737 & $10.25 \%$ & $37.36 \%$ \\
\hline \multicolumn{4}{|c|}{ B. Distributions by CEO-Year } \\
\hline 1992 & 99 & $8.08 \%$ & $20.20 \%$ \\
\hline 1993 & 321 & $6.85 \%$ & $29.90 \%$ \\
\hline 1994 & 378 & $9.52 \%$ & $35.97 \%$ \\
\hline 1995 & 402 & $10.69 \%$ & $40.29 \%$ \\
\hline 1996 & 472 & $9.32 \%$ & $40.04 \%$ \\
\hline 1997 & 536 & $7.08 \%$ & $44.96 \%$ \\
\hline 1998 & 550 & $8.18 \%$ & $45.63 \%$ \\
\hline 1999 & 568 & $6.69 \%$ & $45.77 \%$ \\
\hline 2000 & 529 & $9.82 \%$ & $47.63 \%$ \\
\hline 2001 & 473 & $11.20 \%$ & $44.82 \%$ \\
\hline 2002 & 397 & $13.09 \%$ & $37.02 \%$ \\
\hline 2003 & 513 & $10.33 \%$ & $41.32 \%$ \\
\hline 2004 & 579 & $12.78 \%$ & $35.92 \%$ \\
\hline 2005 & 522 & $11.87 \%$ & $36.39 \%$ \\
\hline 2006 & 493 & $11.96 \%$ & $36.30 \%$ \\
\hline 2007 & 459 & $8.49 \%$ & $35.94 \%$ \\
\hline 2008 & 295 & $11.86 \%$ & $36.94 \%$ \\
\hline 2009 & 304 & $17.76 \%$ & $35.52 \%$ \\
\hline $1992-2005$ & 6339 & $9.78 \%$ & $40.63 \%$ \\
\hline $1992-2009$ & 7890 & $10.22 \%$ & $39.75 \%$ \\
\hline
\end{tabular}

Note: This table shows the distribution of low and high optimism CEOs by CEO observations (Panel A) and by CEO-year observations (Panel B), respectively, from 1992 to 2009. The data are collected from ExecuComp database. Low CEO optimism and high CEO optimism are as defined in table 1.

respectively, which is similar to the figures reported by Biddle et al. (2009) and Glaser et al. (2008).

\section{B. Univariate Analyses}

Table 4 presents the mean (median) differences in investment ratio and firm value for firms with different levels of CEO optimism. The mean (median) investment ratio of firms with high-optimism CEOs is significantly higher than for firms with low-optimism CEOs. This indicates that firms with high-optimism CEOs invest more than firms 
with low-optimism CEOs. If we divide the investment ratio into two proportions, capital investment (Ic) and noncapital investment (In), and compare the investment ratios under different levels of CEO optimism, we also find that both the capital investment ratio and noncapital investment ratio of firms with high-optimism CEOs are significantly higher than those of firms with low-optimism CEOs.

The mean (median) firm value of firms with high-optimism CEOs is also significantly higher than those with low high-optimism CEOs. This implies that such firms generally have higher firm valuations if they have high-optimism CEOs. The univariate comparisons show that managerial optimism could affect the investment behavior and firm valuations as well.

\section{Multivariate Regression Analyses}

\section{Conditional test - Relationship between investment and CEO optimism}

Table 5 presents the regression coefficients and p-value results for the tests of hypotheses $H 1_{a}$ and $H 1_{\mathrm{b}}$. We find the coefficient of HighOpti is 1.29 in Model 2, which is statistically significant at the $5 \%$ level, indicating that a firm with a high-optimism CEO will invest more than firms with other levels of CEO optimism. Our main prediction is that the coefficient of the interaction term HighOpti*UnderInvest will be positive. The results in Models 3 and 4 show that the coefficients of the interaction term are significantly positive. In terms of the economic significance, increasing CEO optimism by one standard deviation increases investment by approximately $0.5826 \%$ among firms that are under-investing. ${ }^{3}$ Given that the mean investment equals $17.09 \%$, this effect represents an increase of $3.41 \%$. These findings provide consistent support for Hypothesis $H 1_{a}$. On the other hand, the coefficient of the interaction term LowOpti*OverInvest is not significant in Models 5 and 6, which is inconsistent with our prediction under $H 1_{b}$. In sum, we find that the empirical evidence partially supports our hypothesis that when firms are more prone to under-invest, high levels of CEO optimism will help improve a firm's investment efficiency. On the other hand, when firms are more prone to over-invest, low levels of CEO optimism will not significantly affect a firm's investment efficiency.

3. The standard deviation of CEO optimism is 0.4815 for the period from 1992 to 2009 . 


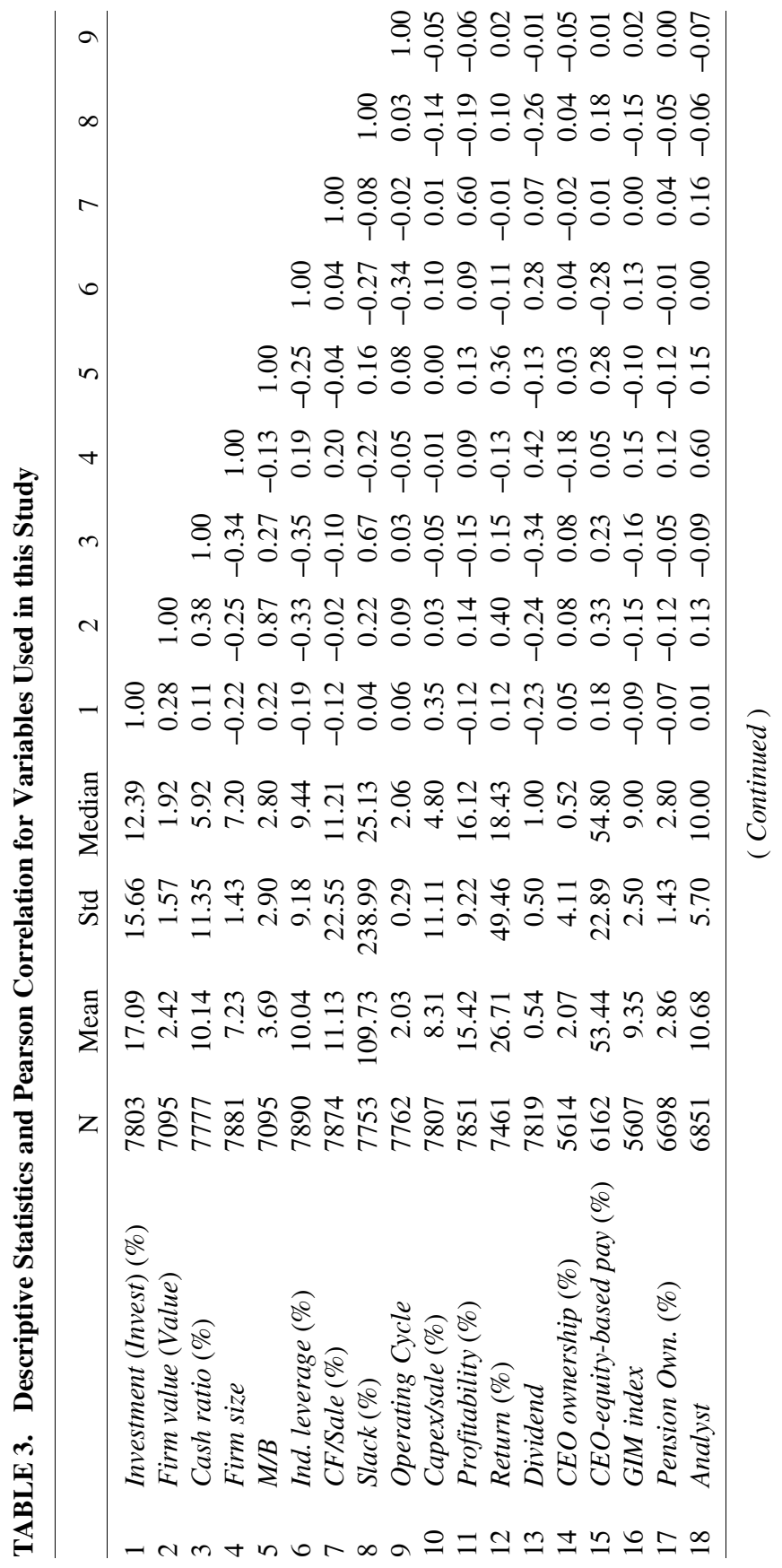




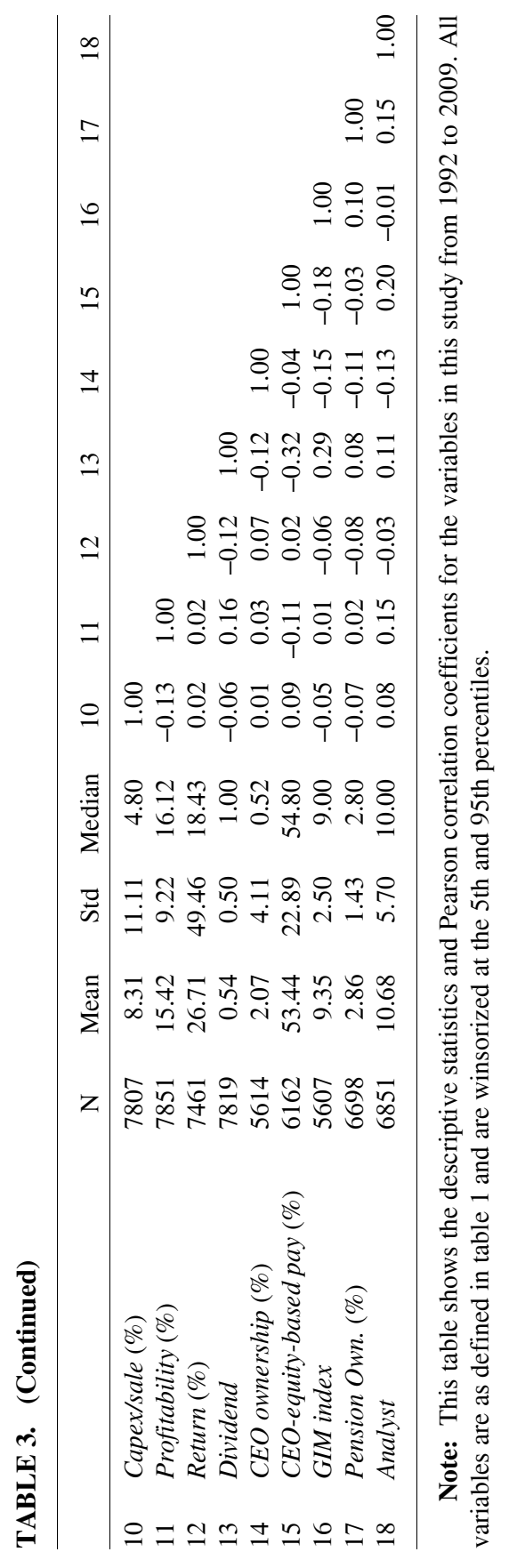




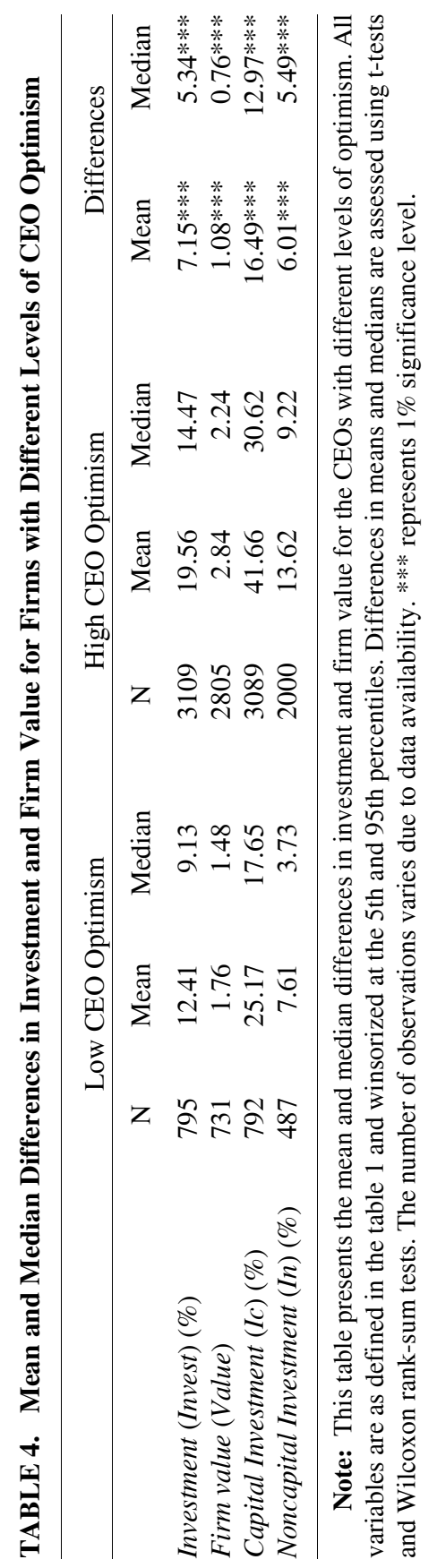


Conditional test - Relationship between firm valuation and CEO optimism

Table 6 presents the regression coefficients and p-value results for the test of hypotheses $\mathrm{H}_{a}$ and $\mathrm{H}_{b}$. The coefficient of HighOpti is 0.29 in Model 2 and statistically significant at the $1 \%$ level, indicating that firms with a high-optimism CEO on average have higher valuations than firms with CEOs with other levels of optimism. The interaction terms HighOpti*UnderInvest in Models 3 and 4 are significantly positive, which are consistent with our prediction. In terms of the economic significance, increasing CEO optimism by one standard deviation increases firm valuation by approximately $11.07 \%$ among firms that are under-investing. Given that the mean firm value equals 2.42 , this effect represents an increase of $4.58 \%$. However, the coefficients of interaction term LowOpti*OverInvest in Models 5 and 6 are not significant, which fails to support $H 2_{b}$. In sum, when firms are prone to under-invest, their firm value increases when they have a highly optimistic CEO, but when firms are prone to over-invest, there is insufficient evidence to demonstrate that firm value will increase when their CEO has a low level of optimism.

\section{Unconditional test}

Our analysis thus far has been conditional on the firm being in a setting where over- or under-investment is more likely. However, it is possible that firms with certain firm characteristics choose optimistic CEOs or induce higher levels of optimism in their CEOs. To explore this issue, we conduct the following tests: first, we investigate the changes in investment ratio and firm value surrounding a high/low optimistic CEO turnover or when CEO optimism becomes high/low; second, we examine the relation between the firm investment ratio and high/low optimism CEOs before they show their optimism attitudes. Explicitly, we replace the dependent variable with the firm's investment in the years prior to the optimistic CEO joining the firm and limit the sample to firm-years prior to the CEO joining. Finally, we estimate a multinomial logistic regression that tests the association between the CEO optimism and the likelihood of over- or under- investing. The empirical results are reported in tables 7 to 9.

Table 7 presents the results for the changes in investment ratio and firm value surrounding a high/low optimistic CEO turnover or when 
TABLE 5. Relationship between Firm Characteristics, CEO Optimism, and Investment

\begin{tabular}{|c|c|c|c|c|c|c|}
\hline Variables & Model 1 & Model 2 & Model 3 & Model 4 & Model 5 & Model 6 \\
\hline Intercept & $\begin{array}{l}10.31 \\
(7.55)^{* * * *}\end{array}$ & $\begin{array}{l}18.95 \\
(4.38)^{* * * *}\end{array}$ & $\begin{array}{l}11.46 \\
(8.34)^{* * * *}\end{array}$ & $\begin{array}{l}20.27 \\
(4.84) * * *\end{array}$ & $\begin{array}{l}11.58 \\
(8.60) * * *\end{array}$ & $\begin{array}{l}20.95 \\
(4.91)^{* * * *}\end{array}$ \\
\hline HighOpti & $\begin{array}{l}2.37 \\
(5.15) * * *\end{array}$ & $\begin{array}{l}1.29 \\
(2.13)^{* *}\end{array}$ & $\begin{array}{l}0.74 \\
(2.47)^{* *}\end{array}$ & $\begin{array}{l}1.21 \\
(2.32)^{* * *}\end{array}$ & & \\
\hline UnderInvest & & & $\begin{array}{l}-4.14 \\
(-5.38) * * *\end{array}$ & $\begin{array}{l}-3.98 \\
(-2.87) * * *\end{array}$ & & \\
\hline $\begin{array}{l}\text { HighOpti } \\
\text { *UnderInvest }\end{array}$ & & & $\begin{array}{l}9.33 \\
(6.63)^{* * * *}\end{array}$ & $\begin{array}{l}10.46 \\
(4.40)^{* * * *}\end{array}$ & & \\
\hline LowOpti & & & & & $\begin{array}{l}-2.22 \\
(-3.98) * * *\end{array}$ & $\begin{array}{l}-1.87 \\
(-2.44) * *\end{array}$ \\
\hline OverInvest & & & & & $\begin{array}{c}0.50 \\
(0.96)\end{array}$ & $\begin{array}{l}2.45 \\
(3.11)^{* * *}\end{array}$ \\
\hline $\begin{array}{l}\text { LowOpti } \\
\text { *OverInvest }\end{array}$ & & & & & $\begin{array}{c}0.13 \\
(0.09)\end{array}$ & $\begin{array}{l}-0.10 \\
(-0.07)\end{array}$ \\
\hline Firm size & & $\begin{array}{l}-2.68 \\
(-3.43)^{* * * *}\end{array}$ & & $\begin{array}{l}-0.94 \\
(-2.61)^{* * *}\end{array}$ & & $\begin{array}{l}-1.20 \\
(-3.21)^{* * * *}\end{array}$ \\
\hline$M / B$ & & $\begin{array}{c}0.01 \\
(1.15)\end{array}$ & & $\begin{array}{l}0.36 \\
(2.79) * * *\end{array}$ & & $\begin{array}{l}0.49 \\
(3.87)^{* * *}\end{array}$ \\
\hline Ind. leverage & & $\begin{array}{c}0.14 \\
(1.52)\end{array}$ & & $\begin{array}{c}0.11 \\
(1.36)\end{array}$ & & $\begin{array}{c}0.15 \\
(1.63)\end{array}$ \\
\hline CF/Sale & & $\begin{array}{l}0.04 \\
(1.98)^{* *}\end{array}$ & & $\begin{array}{l}0.04 \\
(2.04)^{* *}\end{array}$ & & $\begin{array}{l}0.05 \\
(2.34) * *\end{array}$ \\
\hline Operating Cycle & & $\begin{array}{l}-0.85 \\
(-0.55)\end{array}$ & & $\begin{array}{l}-1.55 \\
(-1.02)\end{array}$ & & $\begin{array}{l}-1.03 \\
(-0.67)\end{array}$ \\
\hline Dividend & & $\begin{array}{l}-2.68 \\
(-3.43)^{* * * *}\end{array}$ & & $\begin{array}{l}-2.32 \\
(-2.98)^{* * * *}\end{array}$ & & $\begin{array}{l}-2.66 \\
(-3.40)^{* * *}\end{array}$ \\
\hline Return & & $\begin{array}{c}0.01 \\
(1.15)\end{array}$ & & $\begin{array}{c}0.01 \\
(0.87)\end{array}$ & & $\begin{array}{c}0.01 \\
(1.12)\end{array}$ \\
\hline Slack & & $\begin{array}{l}-0.01 \\
(-5.82)^{* * * *}\end{array}$ & & $\begin{array}{l}-0.01 \\
(-5.67) * * *\end{array}$ & & $\begin{array}{l}-0.01 \\
(-4.76)^{* * * *}\end{array}$ \\
\hline CEO ownership & & $\begin{array}{c}0.08 \\
(1.10)\end{array}$ & & $\begin{array}{c}0.06 \\
(0.85)\end{array}$ & & $\begin{array}{c}0.10 \\
(1.39)\end{array}$ \\
\hline CEO-equity-based $p$ & pay & $\begin{array}{c}0.02 \\
(1.54)\end{array}$ & & $\begin{array}{l}0.02 \\
(1.67)^{*}\end{array}$ & & $\begin{array}{c}0.02 \\
(1.61)\end{array}$ \\
\hline GIM index & & $\begin{array}{l}-0.03 \\
(-0.20)\end{array}$ & & $\begin{array}{l}-0.05 \\
(-0.41)\end{array}$ & & $\begin{array}{l}-0.04 \\
(-0.29)\end{array}$ \\
\hline Pension Own & & $\begin{array}{l}-0.15 \\
(-0.88)\end{array}$ & & $\begin{array}{l}-0.11 \\
(-0.63)\end{array}$ & & $\begin{array}{l}-0.14 \\
(-0.80)\end{array}$ \\
\hline Analyst & & $\begin{array}{c}0.09 \\
(1.27)\end{array}$ & & $\begin{array}{c}0.08 \\
(1.17)\end{array}$ & & $\begin{array}{c}0.12 \\
(1.61)\end{array}$ \\
\hline Year/Industry FE & Yes & Yes & Yes & Yes & Yes & Yes \\
\hline Firm cluster & Yes & Yes & Yes & Yes & Yes & Yes \\
\hline $\mathrm{N}$ & 7741 & 2812 & 7741 & 2812 & 7741 & 2812 \\
\hline $\mathrm{R}^{2}$ & 0.172 & 0.194 & 0.187 & 0.230 & 0.169 & 0.197 \\
\hline
\end{tabular}

( Continued) 
TABLE 5. (Continued)

Note: This table presents the OLS regression estimates of firm characteristics and CEO optimism on investment. All variables are as defined in the table 1 and winsorized at the 5th and 95th percentiles. The model includes year and industry fixed-effects based on the Fama-French 49 industry classifications. t-Statistics are presented in parenthesis below the coefficients and are corrected for heteroskedasticity, and cross-sectional and time-series correlation using a one-way cluster at the firm level. The number of observations varies because of data unavailability. $* * *, * *$, and $*$ represent the $1 \%, 5 \%$, and $10 \%$ significance levels, respectively.

CEO optimism becomes high/low. Year $t$ is defined as the year in which a high/low optimism CEO is turned over or when CEO optimism becomes high/low. Panels A and B of table 7 report the change in investment ratio and firm value relative to year $t-1$ when a high/low optimistic CEO turnover. The mean and median changes in investment ratio and firm value between year $t-1$ and years $t+1, t+2$, and $t+3$ are negative and statistically significant at the $10 \%$ level or better in Panel A, indicating that investment ratio and firm value decrease significantly after a high optimism CEO leaves. Panel B reports that the mean and median changes in investment ratio and firm value between year $t-1$ and years $t+1$ are positive but statistically not significant for those firms with a low optimism CEO turnover. We also investigate the changes in investment ratio and firm value when CEO optimism becomes high/low. The results from Panel $\mathrm{C}$ indicate that investment ratio and firm value significantly increase when CEO optimism becomes high, except for the non-significant increase in investment ratio in year $t+3$. However, no significant decrease is observed in Panel $\mathrm{D}$ when CEO optimism becomes low. The empirical analyses from table 7 indicate that the investment ratio and firm value are partially affected by the level of CEO optimism, especially when the CEOs have a high level of optimism. The investment ratio and firm value are both observed to significantly decrease when a high optimism CEO leaves the firm, but both significantly increase when CEO optimism becomes high.

We further limit our sample to firm-years prior to when CEO optimism becomes high/low and examine the relation between the firm investment ratio and high/low optimistic CEOs as they exhibit their optimism attitudes. The results from table 8 report that the coefficients on HighOpti and LowOpti are both not significant, indicating that firm's investment behavior in past years is not significantly associated with the level of CEO optimism. 
TABLE 6. Relationship between Firm Characteristics, CEO Optimism, and Firm Value

\begin{tabular}{|c|c|c|c|c|c|c|}
\hline Variables & Model 1 & Model 2 & Model 3 & Model 4 & Model 5 & Model 6 \\
\hline Intercept & $\begin{array}{c}1.67 \\
(10.26)^{* * * *}\end{array}$ & $\begin{array}{l}2.08 \\
(5.19)^{* * * *}\end{array}$ & $\begin{array}{c}1.80 \\
(11.59)^{* * * *}\end{array}$ & $\begin{array}{l}2.04 \\
(5.28)^{* * *}\end{array}$ & $\begin{array}{c}1.62 \\
(13.75)^{* * * *}\end{array}$ & $\begin{array}{c}1.93 \\
(5.03)^{* * * *}\end{array}$ \\
\hline HighOpti & $\begin{array}{l}0.51 \\
(9.06) * * *\end{array}$ & $\begin{array}{c}0.29 \\
(4.61)^{* * *}\end{array}$ & $\begin{array}{l}0.41 \\
(6.15)^{* * * *}\end{array}$ & $\begin{array}{l}0.23 \\
(3.05)^{* * *}\end{array}$ & & \\
\hline UnderInvest & & $(-$ & $\begin{array}{l}-0.99 \\
-13.80)^{* * * *}\end{array}$ & $\begin{array}{l}-0.46 \\
(-5.99)^{* * *}\end{array}$ & & \\
\hline $\begin{array}{l}\text { HighOpti } \\
\text { *UnderInvest }\end{array}$ & & & $\begin{array}{l}0.58 \\
(2.69) * * *\end{array}$ & $\begin{array}{l}0.56 \\
(3.54)^{* * * *}\end{array}$ & & \\
\hline LowOpti & & & & & $\begin{array}{l}-0.28 \\
(-4.53)^{* * * *}\end{array}$ & $\begin{array}{l}-0.04 \\
*(-0.58)\end{array}$ \\
\hline OverInvest & & & & & $\begin{array}{c}1.17 \\
(18.39)^{* * *}\end{array}$ & $\begin{array}{c}0.59 \\
*(7.60)^{* * *}\end{array}$ \\
\hline $\begin{array}{l}\text { LowOpti } \\
\text { *OverInvest }\end{array}$ & & & & & $\begin{array}{c}-0.78 \\
(-1.16)\end{array}$ & $\begin{array}{c}-0.34 \\
(-1.05)\end{array}$ \\
\hline Firm size & & $\begin{array}{c}0.00 \\
(0.34)\end{array}$ & & $\begin{array}{l}-0.27 \\
(-7.46)^{* * *}\end{array}$ & & $\begin{array}{l}-0.24 \\
(-6.52) * * *\end{array}$ \\
\hline Capex/Sale & & $\begin{array}{l}0.01 \\
(7.77)^{* * * *}\end{array}$ & & $\begin{array}{l}-0.00 \\
(-0.49)\end{array}$ & & $\begin{array}{l}-0.00 \\
(-0.29)\end{array}$ \\
\hline Profitability & & $\begin{array}{l}0.06 \\
(9.28)^{* * * *}\end{array}$ & & $\begin{array}{l}0.06 \\
(8.82)^{* * *}\end{array}$ & & $\begin{array}{l}0.06 \\
(9.10)^{* * *}\end{array}$ \\
\hline Return & & $\begin{array}{c}0.01 \\
(13.06)^{* * * *}\end{array}$ & & $\begin{array}{c}0.01 \\
(13.31)^{* * *}\end{array}$ & & $\begin{array}{c}0.01 \\
(12.61)^{* * * *}\end{array}$ \\
\hline Ind. leverage & & $\begin{array}{l}-0.02 \\
(-2.95) * * *\end{array}$ & & $\begin{array}{l}-0.02 \\
(-3.52)^{* * *}\end{array}$ & & $\begin{array}{l}-0.02 \\
(-3.53)^{* * *}\end{array}$ \\
\hline CEO ownership & & $\begin{array}{c}0.00 \\
(0.34)\end{array}$ & & $\begin{array}{c}0.00 \\
(0.39)\end{array}$ & & $\begin{array}{c}0.00 \\
(0.29)\end{array}$ \\
\hline CEO-equity-based & pay & $\begin{array}{l}0.01 \\
(7.77)^{* * *}\end{array}$ & & $\begin{array}{l}0.01 \\
(7.59)^{* * *}\end{array}$ & & $\begin{array}{l}0.01 \\
(7.63)^{* * * *}\end{array}$ \\
\hline GIM index & & $\begin{array}{c}0.00 \\
(0.26)\end{array}$ & & $\begin{array}{c}0.00 \\
(0.43)\end{array}$ & & $\begin{array}{l}-0.00 \\
(-0.01)\end{array}$ \\
\hline Pension Own & & $\begin{array}{l}-0.04 \\
(-1.87)^{*}\end{array}$ & & $\begin{array}{l}-0.04 \\
(-1.90)^{*}\end{array}$ & & $\begin{array}{l}-0.05 \\
(-2.92)^{* * *}\end{array}$ \\
\hline Analyst & & $\begin{array}{c}0.08 \\
(10.84)^{* * * *}\end{array}$ & & $\begin{array}{c}0.07 \\
(10.34)^{* * * *}\end{array}$ & & $\begin{array}{c}0.07 \\
(10.04)^{* * *}\end{array}$ \\
\hline Year/Industry FE & Yes & $\mathrm{Ye}$ & $\mathrm{Ye}$ & $\mathrm{Ye}$ & $\mathrm{Ye}$ & Yes \\
\hline Firm cluster & Yes & Yes & Yes & Yes & Yes & Yes \\
\hline $\mathrm{N}$ & 7042 & 2901 & 7042 & 2901 & 7042 & 2901 \\
\hline $\mathrm{R}^{2}$ & 0.270 & 0.540 & 0.317 & 0.551 & 0.331 & 0.551 \\
\hline
\end{tabular}

Note: This table presents the OLS regression estimates of firm characteristics and CEO optimism on firm value. All variables are as defined in the table 1 and winsorized at the 5th and 95th percentiles. The model includes year and industry fixed-effects based on the Fama-French 49 industry classifications. t-Statistics are presented in parenthesis below the coefficients and are corrected for heteroskedasticity, and cross-sectional and time-series correlation using a one-way cluster at the firm level. The number of observations varies because of data unavailability. $* * *, * *$, and $*$ represent the $1 \%, 5 \%$, and $10 \%$ significance levels, respectively. 
The results of testing the association between the CEO optimism and the likelihood of over- or under- investing are reported in table 9. The coefficient associated with HighOpti (high CEO optimism) in Model 1 of Panel A is significantly negative, indicating that high CEO optimism significantly decreases the possibility of underinvestment, which is also consistent with our main results, reported in previous tables. However, the coefficient associated with LowOpti (low CEO optimism) in Model 4 of Panel B is not significant, indicating that low CEO optimism does not significantly decrease the possibility of overinvestment. The results from table 5 to table 9 generally support our hypothesis $H 1_{a}$ that firms with a high optimism CEO are more likely to decrease the possibility of underinvestment and improve the investment efficiency of the firm, but the above implication does not apply to CEOs with a low level of optimism.

\section{Robustness checks - Another metric of over- or under-investment}

We further implement several tests to ensure that the above results are not contaminated by other important factors and bias our results. First, we use another approach to classify the tendency of firms to over- or under-invest. Similar to Biddle et al. (2009), we estimate a firm-specific model of investment as a function of growth opportunities (as measured by sales growth of previous year) for each industry-year based on the Fama and French 49-industry classification for all industries with at least 20 observations in a given year. The deviations from predicted investment each year from the regression are used to classify firms as under- or over-invested. Firm-year observations in the bottom quartile (i.e., the most negative residuals) are classified as under-investment, and observations in the top quartile (i.e., the most positive residuals) are classified as over-investment. We then re-estimate the regression specifications (1) and (2), reporting the results in section A (Models 1 and 2) of Panel A(B) in table 10. The coefficients of the interaction term HighOpti*UnderInvest are still significantly positive in Model 1 for both panels, consistent with the results in table 5 and table 6 .

Robustness checks - Other top executives' optimism and different sample period

We also wondered whether there is a correlation between the CEO optimism and other top executives' optimism. Because the ExecuComp 


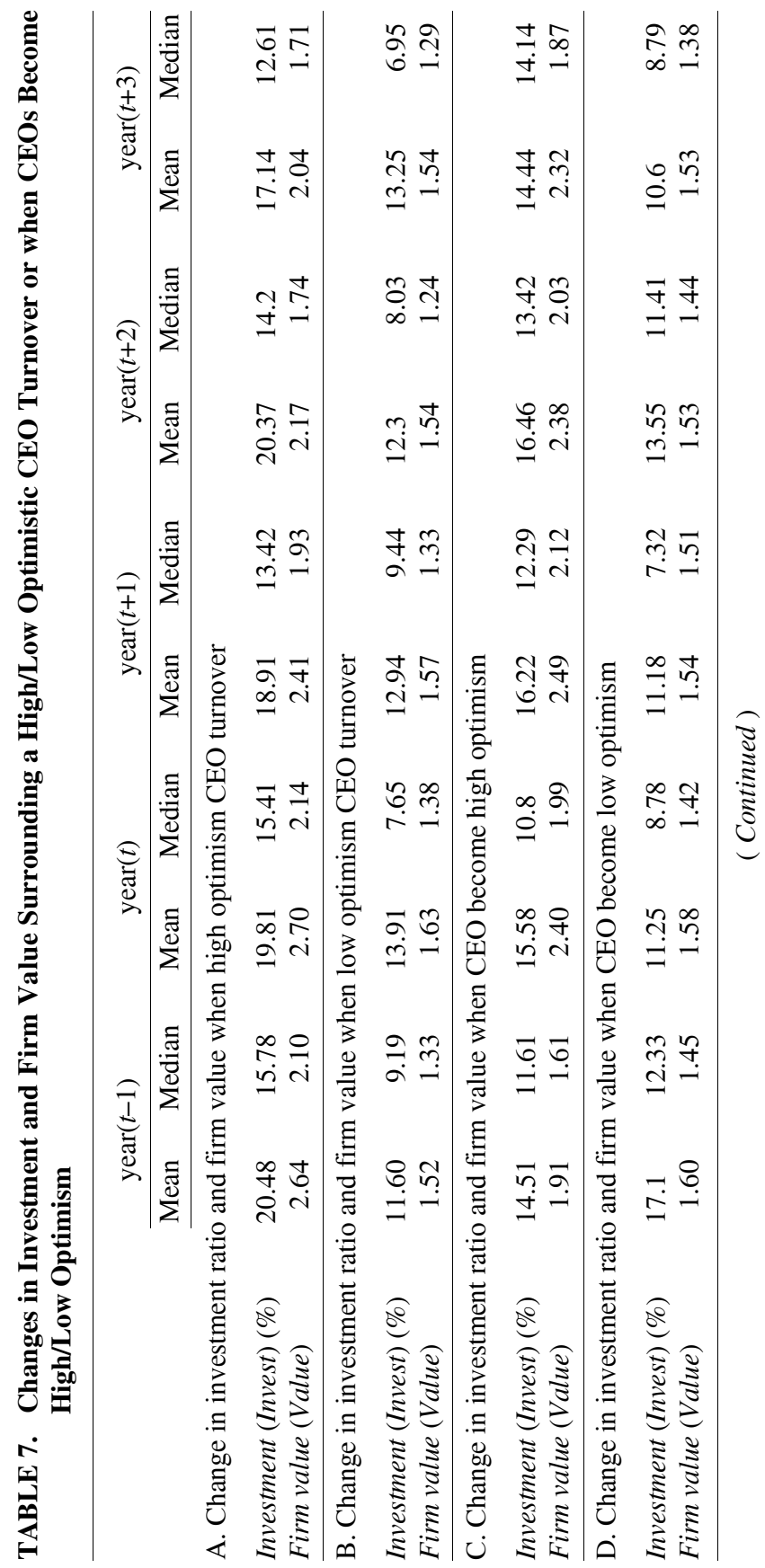




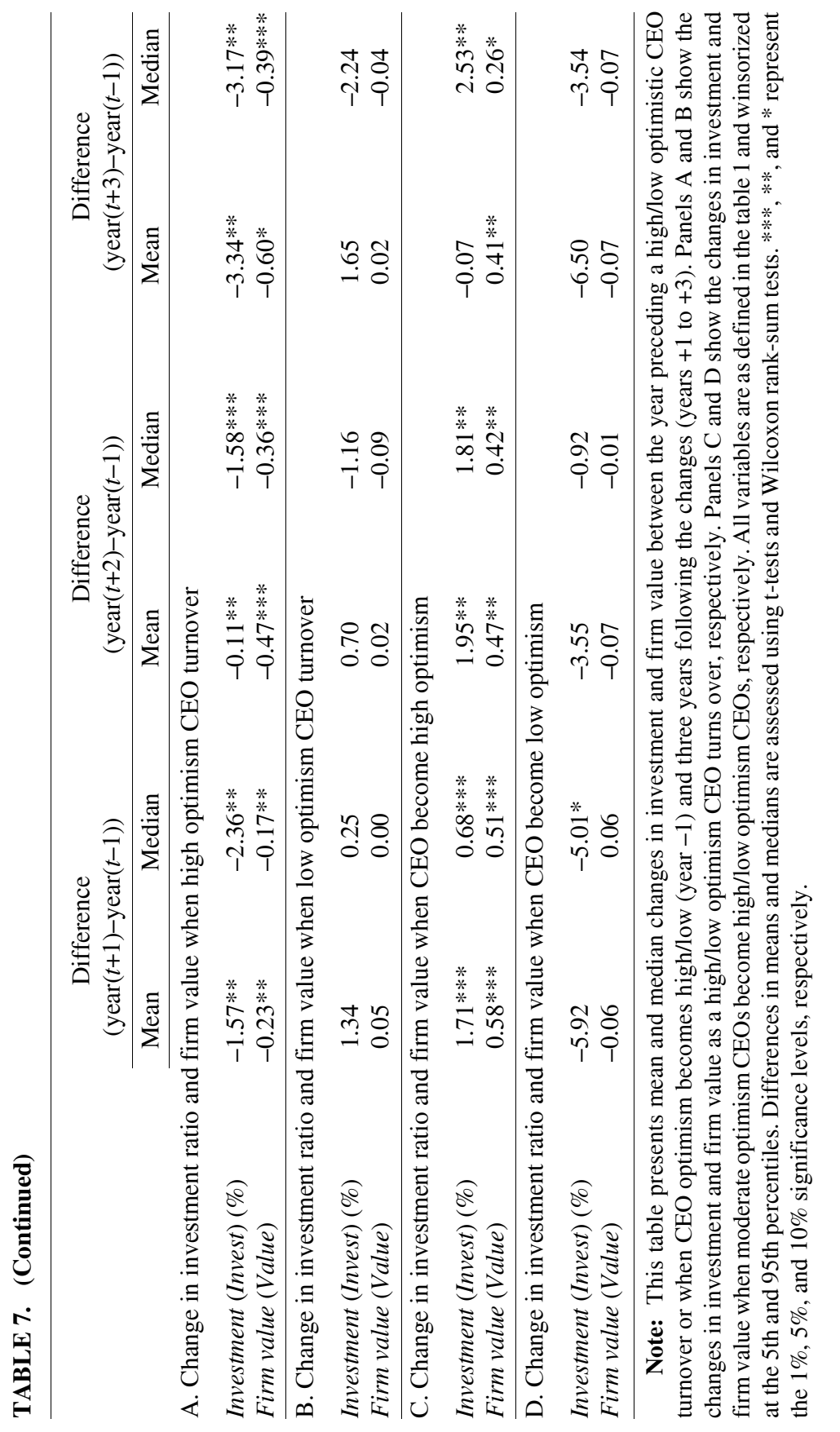


TABLE 8. Relationship between Prior Investment Ratio and CEO Optimism

\begin{tabular}{|c|c|c|}
\hline Variables & Model 1 & Model 2 \\
\hline Intercept & $\begin{array}{l}36.53 \\
(2.22)^{* *}\end{array}$ & $\begin{array}{l}36.57 \\
(2.22)^{* *}\end{array}$ \\
\hline HighOpti & $\begin{array}{c}0.31 \\
(0.25)\end{array}$ & \\
\hline LowOpti & & $\begin{array}{l}-0.71 \\
(-0.53)\end{array}$ \\
\hline Firm size & $\begin{array}{l}-1.43 \\
(-3.10)^{* * *}\end{array}$ & $\begin{array}{l}-1.43 \\
(-3.09)^{* * *}\end{array}$ \\
\hline$M / B$ & $\begin{array}{c}0.65 \\
(1.89)^{*}\end{array}$ & $\begin{array}{c}0.65 \\
(1.89)^{*}\end{array}$ \\
\hline Ind. leverage & $\begin{array}{l}-0.11 \\
(-1.15)\end{array}$ & $\begin{array}{l}-0.11 \\
(-1.17)\end{array}$ \\
\hline CF/Sale & $\begin{array}{c}0.06 \\
(1.10)\end{array}$ & $\begin{array}{c}0.06 \\
(1.10)\end{array}$ \\
\hline Operating Cycle & $\begin{array}{l}-1.17 \\
(-0.69)\end{array}$ & $\begin{array}{l}-1.18 \\
(-0.70)\end{array}$ \\
\hline Dividend & $\begin{array}{l}-1.49 \\
(-1.34)\end{array}$ & $\begin{array}{l}-1.46 \\
(-1.32)\end{array}$ \\
\hline Return & $\begin{array}{c}0.00 \\
(0.46)\end{array}$ & $\begin{array}{c}0.00 \\
(0.47)\end{array}$ \\
\hline Slack & $\begin{array}{l}-0.01 \\
(-2.62)^{* * *}\end{array}$ & $\begin{array}{l}-0.01 \\
(-2.61)^{* * *}\end{array}$ \\
\hline CEO ownership & $\begin{array}{c}0.01 \\
(0.13)\end{array}$ & $\begin{array}{c}0.01 \\
(0.11)\end{array}$ \\
\hline CEO-equity-based pay & $\begin{array}{c}0.01 \\
(0.97)\end{array}$ & $\begin{array}{c}0.01 \\
(0.96)\end{array}$ \\
\hline GIM index & $\begin{array}{l}-0.19 \\
(-1.24)\end{array}$ & $\begin{array}{l}-0.19 \\
(-1.23)\end{array}$ \\
\hline Pension Own & $\begin{array}{l}-0.02 \\
(-0.08)\end{array}$ & $\begin{array}{l}-0.02 \\
(-0.08)\end{array}$ \\
\hline Analyst & $\begin{array}{l}0.24 \\
(2.57)^{* *}\end{array}$ & $\begin{array}{l}0.24 \\
(2.57)^{* *}\end{array}$ \\
\hline Year/Industry FE & Yes & Yes \\
\hline Firm cluster & Yes & Yes \\
\hline $\mathrm{N}$ & 1277 & 1277 \\
\hline $\mathrm{R}^{2}$ & 0.193 & 0.194 \\
\hline
\end{tabular}

Note: This table presents the OLS regression estimates of the CEO optimism (year $t$ ) on prior firm investment (year $t-1$ ). The dependent variable is firm investment prior to the year when CEO optimism becomes high/low. We limit our sample to firm-year observations prior to when a CEO shows her/his optimism attitude. All variables are as defined in the table 1 and winsorized at the 5 th and 95 th percentiles. The model includes year and industry fixed-effects based on the Fama-French 49 industry classifications. t-Statistics are presented in parenthesis below the coefficients and are corrected for heteroskedasticity, and cross-sectional and time-series correlation using a one-way cluster at the firm level. The number of observations varies because of data unavailability. $* * *, * *$, and $*$ represent the $1 \%, 5 \%$, and $10 \%$ significance levels, respectively. 
database also provides information about the stock option holdings and exercise data for top executives of a firm, we can solve this query by identifying the optimism of other top executives within the firm using a method similar to that for calculating CEO optimism and investigate the relation between the investment efficiency and other top executives' optimism. ${ }^{4}$ Section B (Models 3 and 4) of Panel A(B) in table 10 shows that a high level of optimism among other top executives in firms exhibiting underinvestment will significantly improve the investment efficiency and therefore enhance firm valuation. We also implement the same test during the period from 1992 to 2005 in the section C (Models 5 and 6) to avoid the sample selection problem, and the results still hold. ${ }^{5}$

Robustness checks - Different measures of investment ratio

Our measure of investment spending includes both capital expenditures and non-capital expenditures. As a robustness check, we decompose the overall investment ratio and consider two components, Capital investment, which is defined as the capital expenditures, scaled by lagged property, plant, and equipment of the previous year, and Noncapital investment, defined as the sum of $\mathrm{R} \& \mathrm{D}$ expenditures and acquisitions, scaled by lagged total assets. We then re-estimate our main model using these two measures of investment ratios. Table 11 still shows findings similar to those of the main results displayed in table 5.

Robustness checks - Relationship between CEO optimism, investment efficiency, and firm valuation

We have so far examined how CEO optimism affects the investment efficiency and firm value. However, we wonder whether the correlation between high firm value and high CEO optimism is due to high investment in these firms. To explore this issue, we use the two-stage least squares (2SLS) method by first estimating Eq. (1), then we use the

4. We also find that the correlation coefficient between CEO optimism and other top executives' optimism is 0.2443 during the sample period.

5. The reason we set the test period from 1992 to 2005 is because Campbell et al. (2011) is the first to use this measure of CEO optimism and investigate firm performance based on CEO turnover. Their study implies that the level of CEO optimism is associated with investment level of a firm. 
TABLE 9. Multi-Nominal Regressions Analyses of the Relationship between CEO Optimism and the Likelihood of Over- or Under- Investing

\begin{tabular}{|c|c|c|c|c|}
\hline & \multicolumn{2}{|c|}{ A. } & \multicolumn{2}{|c|}{ B. } \\
\hline & Model 1 & Model 2 & Model 3 & Model 4 \\
\hline & $\begin{array}{c}\text { Under } \\
\text { Investment }\end{array}$ & $\begin{array}{c}\text { Over } \\
\text { Investment }\end{array}$ & $\begin{array}{c}\text { Under } \\
\text { Investment }\end{array}$ & $\begin{array}{c}\text { Over } \\
\text { Investment }\end{array}$ \\
\hline Intercept & $\begin{array}{l}-2.13 \\
(8.64) * * *\end{array}$ & $\begin{array}{r}0.483 \\
(0.59)\end{array}$ & $\begin{array}{l}-2.177 \\
(9.09)^{* * *}\end{array}$ & $\begin{array}{l}0.624 \\
\text { (1) }\end{array}$ \\
\hline HighOpti & $\begin{array}{l}-0.118 \\
(6.9)^{* * *}\end{array}$ & $\begin{array}{c}0.274 \\
(5.5)^{* *}\end{array}$ & & \\
\hline LowOpti & & & $\begin{array}{r}0.065 \\
(0.16)\end{array}$ & $\begin{array}{r}0.047 \\
(0.05)\end{array}$ \\
\hline Firm size & $\begin{array}{c}0.459 \\
(46.39)^{* * *}\end{array}$ & $\begin{array}{c}-0.691 \\
(104.03)^{* * * *}\end{array}$ & $\begin{array}{c}0.458 \\
(46.05)^{* * *}\end{array}$ & $\begin{array}{c}-0.68 \\
(101.8)^{* * *}\end{array}$ \\
\hline$M / B$ & $\begin{array}{l}-0.345 \\
(67.84)^{* * * *}\end{array}$ & $\begin{array}{l}0.059 \\
(8.93)^{* * *}\end{array}$ & $\begin{array}{l}-0.352 \\
(71.31)^{* * * *}\end{array}$ & $\begin{array}{c}0.063 \\
(10.22)^{* * * *}\end{array}$ \\
\hline Ind. leverage & $\begin{array}{l}-0.043 \\
(30.34)^{* * *}\end{array}$ & $\begin{array}{c}0.065 \\
(84.3)^{* * * *}\end{array}$ & $\begin{array}{l}-0.043 \\
(30.77)^{* * *}\end{array}$ & $\begin{array}{c}0.065 \\
(84.09) * * *\end{array}$ \\
\hline CF/Sale & $\begin{array}{l}-0.012 \\
(4.87)^{* *}\end{array}$ & $\begin{array}{c}0.016 \\
(10.8)^{* * *}\end{array}$ & $\begin{array}{l}-0.013 \\
(5.14)^{* *}\end{array}$ & $\begin{array}{c}0.017 \\
(11.57)^{* * * *}\end{array}$ \\
\hline Operating Cycle & $\begin{array}{c}0.22 \\
(0.91)\end{array}$ & $\begin{array}{c}-0.008 \\
(0.01)\end{array}$ & $\begin{array}{l}0.23 \\
(1)\end{array}$ & $\begin{array}{c}-0.033 \\
(0.03)\end{array}$ \\
\hline Dividend & $\begin{array}{c}-0.188 \\
(1.78)\end{array}$ & $\begin{array}{c}0.088 \\
(0.42)\end{array}$ & $\begin{array}{r}-0.177 \\
(1.59)\end{array}$ & $\begin{array}{r}0.055 \\
(0.17)\end{array}$ \\
\hline Return & $\begin{array}{l}-0.003 \\
(2.55)\end{array}$ & $\begin{array}{r}0.001 \\
(0.49)\end{array}$ & $\begin{array}{c}-0.003 \\
(2.54)\end{array}$ & $\begin{array}{r}0.001 \\
(0.55)\end{array}$ \\
\hline Slack & $\begin{array}{c}-0.048 \\
(154.47)^{* * *}\end{array}$ & $\begin{array}{c}0.003 \\
(72.9)^{* * *}\end{array}$ & $\begin{array}{c}-0.048 \\
(155.64)^{* * *}\end{array}$ & $\begin{array}{c}0.003 \\
(73.7)^{* * *}\end{array}$ \\
\hline CEO ownership & $\begin{array}{c}0.014 \\
(0.65)\end{array}$ & $\begin{array}{l}0.041 \\
(9.74)^{* * * *}\end{array}$ & $\begin{array}{r}0.012 \\
(0.52)\end{array}$ & $\begin{array}{c}0.043 \\
(11.18)^{* * * *}\end{array}$ \\
\hline CEO-equity-based pay & $\begin{array}{c}0.006 \\
(4.13)^{* *}\end{array}$ & $\begin{array}{r}0.004 \\
(2.34)\end{array}$ & $\begin{array}{c}0.005 \\
(4.06)^{* *}\end{array}$ & $\begin{array}{r}0.005 \\
(2.69)\end{array}$ \\
\hline GIM index & $\begin{array}{c}0.04 \\
(2.94)^{*}\end{array}$ & $\begin{array}{c}0.018 \\
(0.53)\end{array}$ & $\begin{array}{c}0.04 \\
(2.95)^{*}\end{array}$ & $\begin{array}{r}0.012 \\
(0.24)\end{array}$ \\
\hline Pension Own & $\begin{array}{c}0.032 \\
(0.61)\end{array}$ & $\begin{array}{l}0.111 \\
(8.26)^{* * *}\end{array}$ & $\begin{array}{l}0.035 \\
(0.76)\end{array}$ & $\begin{array}{l}0.102 \\
(7.06) * * *\end{array}$ \\
\hline Analyst & $\begin{array}{l}-0.06 \\
(22.66)^{* * *} \\
\end{array}$ & $\begin{array}{c}0.058 \\
(20.71)^{* * *} \\
\end{array}$ & $\begin{array}{l}-0.06 \\
(22.27)^{* * *}\end{array}$ & $\begin{array}{c}0.058 \\
(20.84)^{* * * *}\end{array}$ \\
\hline Firm cluster & & & & \\
\hline $\mathrm{P} \quad \mathrm{I}=\mathrm{O}$ & $\begin{array}{l}\text { Under Inv } \\
\text { Over Inve } \\
\text { (Referen }\end{array}$ & $\begin{array}{l}\text { tment }=616 \\
\text { ment }=491 \\
s=1742)\end{array}$ & $\begin{array}{l}\text { Under Inve } \\
\text { Over Inve } \\
\text { (Referen }\end{array}$ & $\begin{array}{l}\text { nent }=616 \\
\text { nent }=491 \\
=1742)\end{array}$ \\
\hline Pseudo $\mathrm{R}^{2}$ & & & & \\
\hline
\end{tabular}

( Continued) 
TABLE 9. (Continued)

Note: This table presents the results from multinomial logit pooled regressions. The dependent variable is based on the level of firm over- or under-investment. Firm-year observations in the bottom quartile of firm average ranked value of cash and leverage are classified as under-investment, observations in the top quartile are classified as over-investment, and the observations in the middle two quartiles are classified as the benchmarking group. Panel A(B) presents the results for a model predicting the likelihood that a firm is likely to under- or overinvest when a firm has high(low) optimism CEO. Other variables are as defined in the table 1 and winsorized at the 5th and 95th percentiles. $\mathrm{t}$-Statistics are presented in parenthesis below the coefficients and are corrected for heteroskedasticity, and clustering of observations by firm. ***, **, and * represent the $1 \%$, $5 \%$, and $10 \%$ significance levels, respectively.

fitted value from Eq. (1) to estimate the following model:

$$
\text { Value }_{i t}=\beta_{0}+\beta_{1} \text { investment }_{i t}+\beta_{i} \sum_{\text {controls }_{i t}}+\varepsilon_{i t}
$$

Table 12 reports the estimates of our 2SLS regressions. We find that the coefficient of investment is significantly positive in Model 1, indicating that underinvested firms with high CEO optimism exhibit more efficient investment decisions, which in turn increase firm value. However, we do not find a significant relation between the improvement in investment efficiency and firm value for an over-invested firm with low CEO optimism.

Relationship between investment/firm value, financial constraints, and CEO optimism

Previous studies show that high-optimism CEOs display greater investment-cash flow sensitivity in financially constrained firms (Heaton, 2002; Lin et al., 2005). However, it is unclear how CEO optimism affects investment decisions under financial constraints. We conjecture that high-optimism optimism CEOs of financial constrained firms will still be willing to invest because they may overestimate the payoff the projects and underestimate the risk. Table 13 reports the OLS regression coefficients of investment on CEO optimism and financial constraints. We measure an index of financial constraints for each firm based on the work of Kaplan and Zingales (1997). Each year we measure the Kaplan-Zingales index as the proxy for firm's financial 


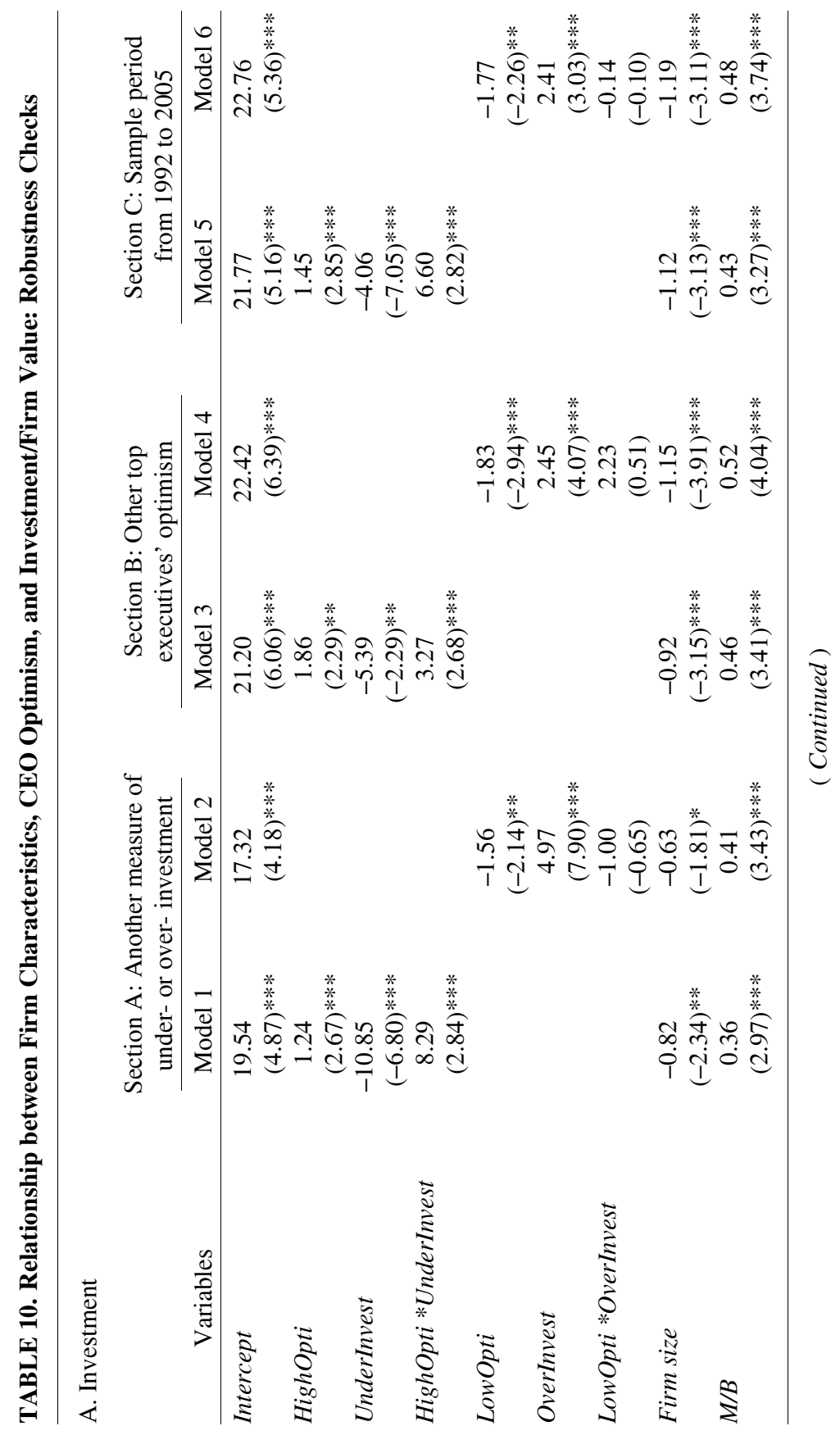




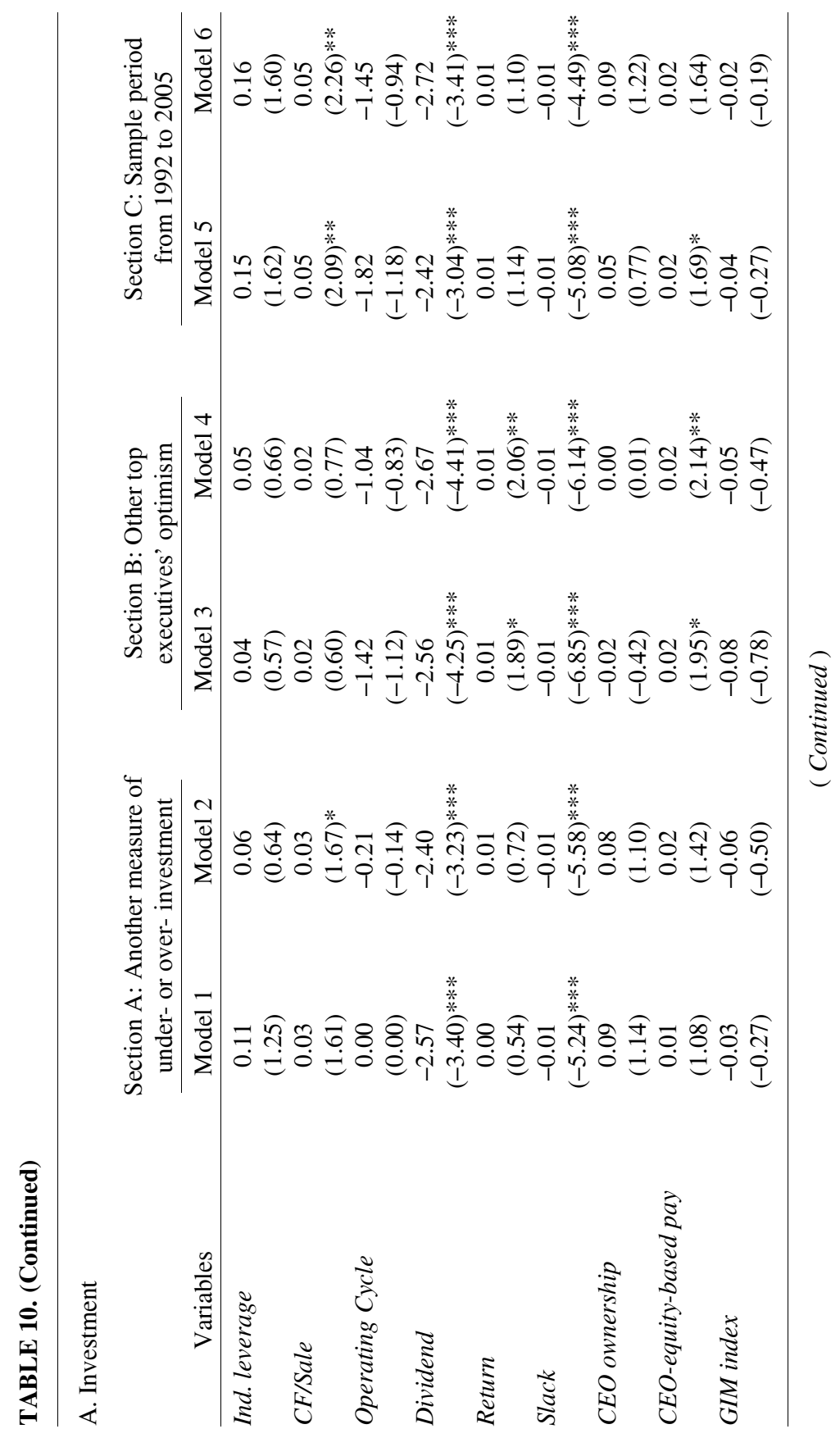




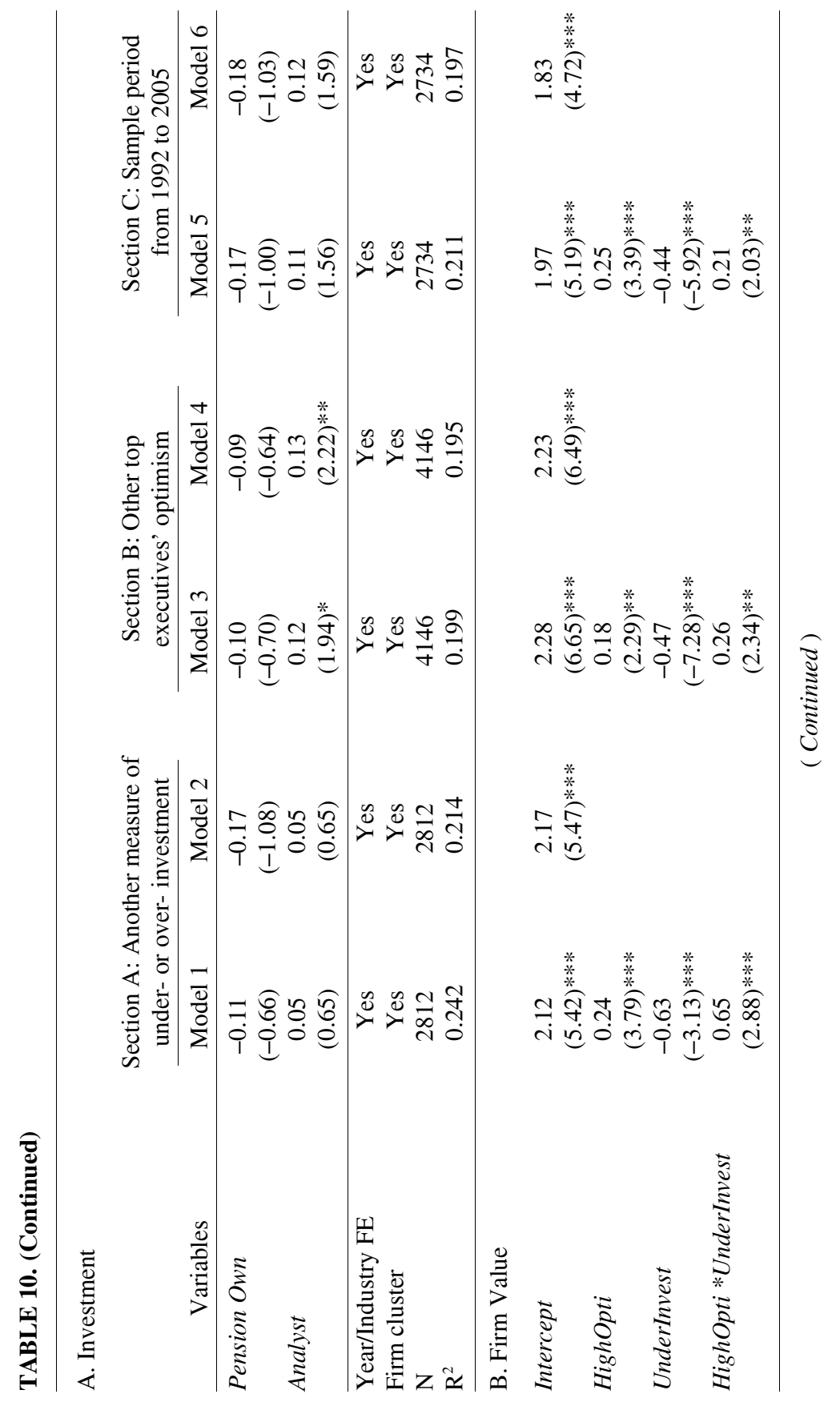




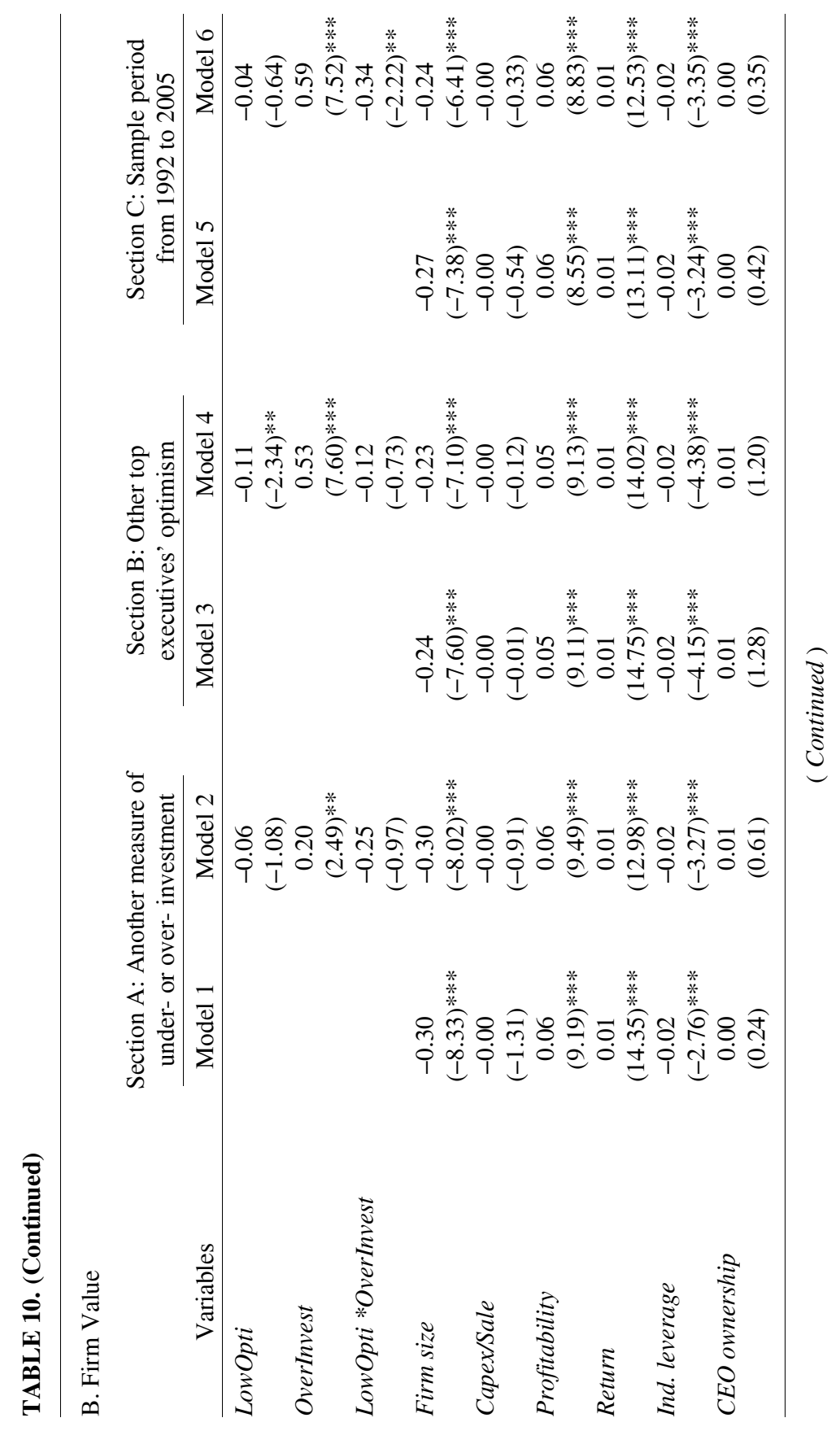




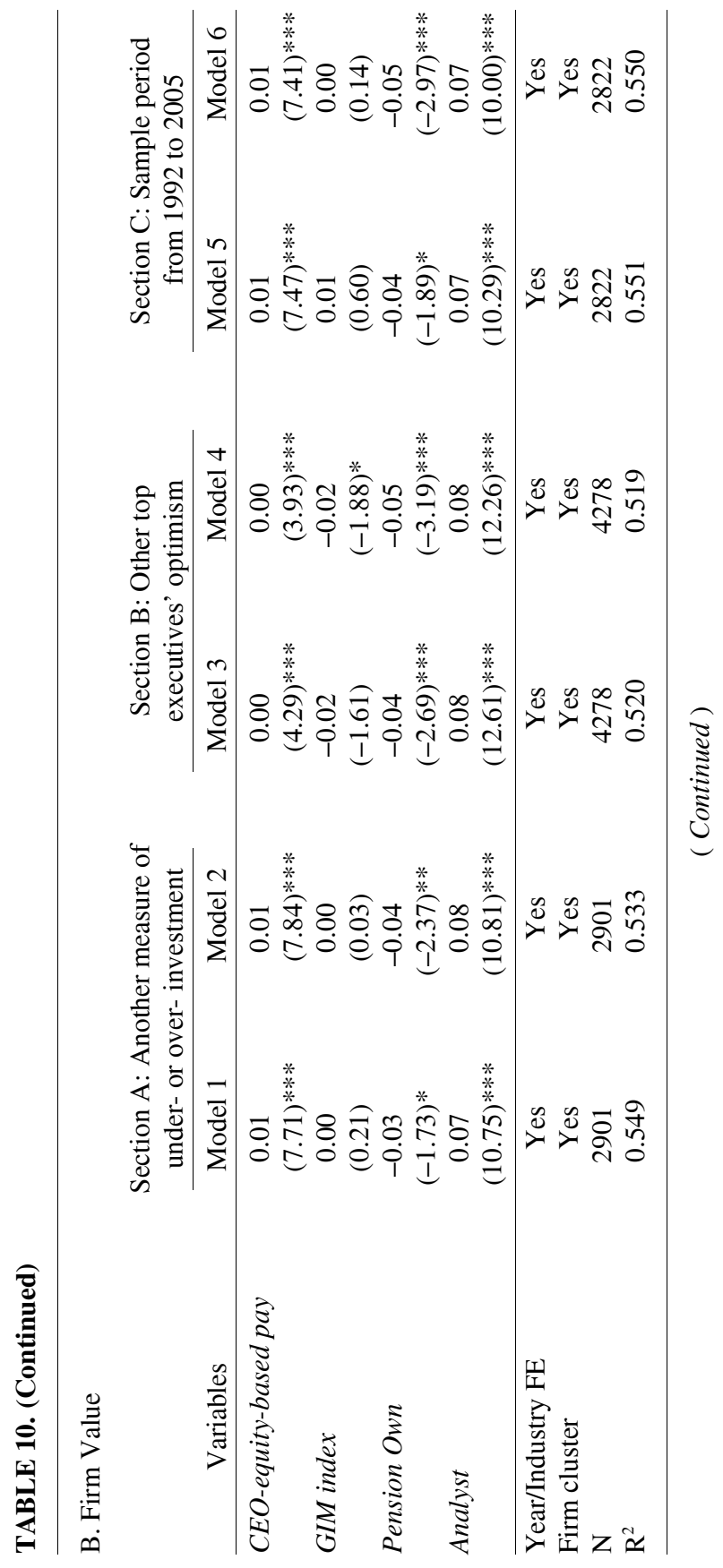




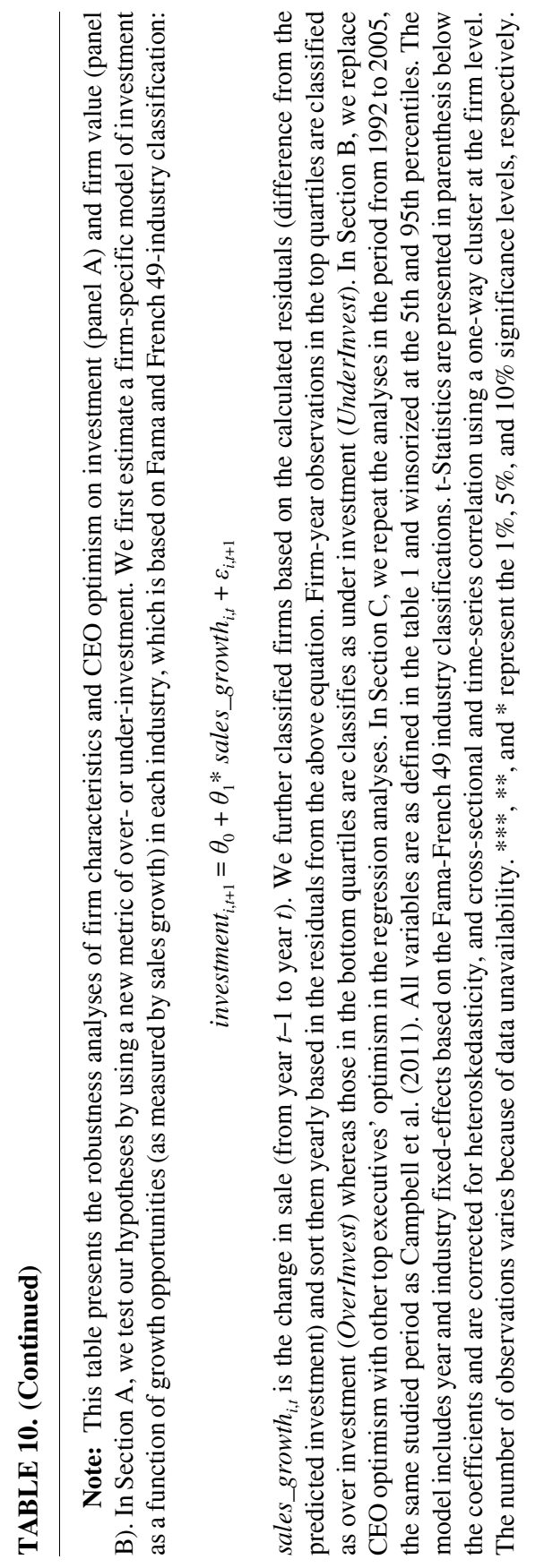


TABLE 11. Relationship between Firm Characteristics and CEO Optimism: Different Measures of Investment Ratios

\begin{tabular}{|c|c|c|c|c|}
\hline \multirow[b]{2}{*}{ Variables } & \multicolumn{2}{|c|}{ A. Capital Investment } & \multicolumn{2}{|c|}{ B. Noncapital Investment } \\
\hline & Model 1 & Model 2 & Model 3 & Model 4 \\
\hline Intercept & $\begin{array}{l}44.32 \\
(6.61) * * *\end{array}$ & $\begin{array}{l}45.82 \\
(6.79) * * *\end{array}$ & $\begin{array}{l}-6.90 \\
(-1.23)\end{array}$ & $\begin{array}{l}-5.54 \\
(-0.98)\end{array}$ \\
\hline HighOpti & $\begin{array}{l}1.71 \\
(2.49)^{* *}\end{array}$ & & $\begin{array}{l}1.17 \\
(2.46)^{* *}\end{array}$ & \\
\hline UnderInvest & $\begin{array}{l}-5.08 \\
(-2.01)^{* *}\end{array}$ & & $\begin{array}{l}-4.21 \\
(-2.09)^{* *}\end{array}$ & \\
\hline HighOpti *UnderInvest & $\begin{array}{l}4.31 \\
(3.94)^{* * * *}\end{array}$ & & $\begin{array}{l}11.79 \\
(3.29)^{* * * *}\end{array}$ & \\
\hline LowOpti & & $\begin{array}{l}-3.19 \\
(-3.35)^{* * *}\end{array}$ & & $\begin{array}{l}-1.70 \\
(-2.12)^{* *}\end{array}$ \\
\hline OverInvest & & $\begin{array}{c}0.05 \\
(0.04)\end{array}$ & & $\begin{array}{l}1.73 \\
(2.05)^{* *}\end{array}$ \\
\hline LowOpti *OverInvest & & $\begin{array}{c}0.09 \\
(0.03)\end{array}$ & & $\begin{array}{c}-0.37 \\
(-0.23)\end{array}$ \\
\hline Firm size & $\begin{array}{l}-3.42 \\
(-5.06)^{* * *}\end{array}$ & $\begin{array}{l}-3.64 \\
(-5.62) * * *\end{array}$ & $\begin{array}{c}-0.13 \\
(-0.28)\end{array}$ & $\begin{array}{c}-0.34 \\
(-0.71)\end{array}$ \\
\hline$M / B$ & $\begin{array}{l}0.89 \\
(3.70)^{* * * *}\end{array}$ & $\begin{array}{l}1.05 \\
(4.36)^{* * * *}\end{array}$ & $\begin{array}{c}0.30 \\
(1.84)^{*}\end{array}$ & $\begin{array}{l}0.41 \\
(2.74)^{* * *}\end{array}$ \\
\hline Ind. leverage & $\begin{array}{l}-0.22 \\
(-2.04) * *\end{array}$ & $\begin{array}{l}-0.18 \\
(-1.74)^{*}\end{array}$ & $\begin{array}{c}0.12 \\
(1.14)\end{array}$ & $\begin{array}{c}0.15 \\
(1.19)\end{array}$ \\
\hline CF/Sale & $\begin{array}{l}0.10 \\
(2.41)^{* *}\end{array}$ & $\begin{array}{l}0.11 \\
(2.51)^{* *}\end{array}$ & $\begin{array}{l}-0.06 \\
(-2.15)^{* *}\end{array}$ & $\begin{array}{l}-0.06 \\
(-2.00)^{* *}\end{array}$ \\
\hline Operating Cycle & $\begin{array}{c}2.62 \\
(0.92)\end{array}$ & $\begin{array}{c}2.81 \\
(0.98)\end{array}$ & $\begin{array}{c}4.10 \\
(1.78)^{*}\end{array}$ & $\begin{array}{c}3.93 \\
(1.75)^{*}\end{array}$ \\
\hline Dividend & $\begin{array}{l}-5.24 \\
(-4.01)^{* * *}\end{array}$ & $\begin{array}{l}-5.30 \\
(-4.00) * * *\end{array}$ & $\begin{array}{l}-2.01 \\
(-2.31)^{* *}\end{array}$ & $\begin{array}{l}-2.22 \\
(-2.53) * *\end{array}$ \\
\hline Return & $\begin{array}{l}-0.03 \\
(-2.24)^{* *}\end{array}$ & $\begin{array}{l}-0.03 \\
(-2.07) * *\end{array}$ & $\begin{array}{c}0.01 \\
(1.25)\end{array}$ & $\begin{array}{c}0.01 \\
(1.33)\end{array}$ \\
\hline Slack & $\begin{array}{l}0.01 \\
(3.74)^{* * *}\end{array}$ & $\begin{array}{l}0.02 \\
(3.62)^{* * * *}\end{array}$ & $\begin{array}{c}-0.00 \\
(-1.09)\end{array}$ & $\begin{array}{l}-0.00 \\
(-0.63)\end{array}$ \\
\hline CEO ownership & $\begin{array}{c}0.11 \\
(0.56)\end{array}$ & $\begin{array}{c}0.12 \\
(0.59)\end{array}$ & $\begin{array}{c}-0.09 \\
(-0.98)\end{array}$ & $\begin{array}{c}-0.07 \\
(-0.78)\end{array}$ \\
\hline CEO-equity-based pay & $\begin{array}{l}0.08 \\
(4.03) * * *\end{array}$ & $\begin{array}{l}0.08 \\
(3.95)^{* * *}\end{array}$ & $\begin{array}{c}0.01 \\
(0.78)\end{array}$ & $\begin{array}{c}0.01 \\
(0.78)\end{array}$ \\
\hline GIM index & $\begin{array}{l}-0.52 \\
(-2.45)^{* *}\end{array}$ & $\begin{array}{l}-0.56 \\
(-2.67) * * *\end{array}$ & $\begin{array}{c}0.11 \\
(0.71)\end{array}$ & $\begin{array}{c}0.13 \\
(0.91)\end{array}$ \\
\hline Pension Own & $\begin{array}{l}-0.56 \\
(-1.83)^{*}\end{array}$ & $\begin{array}{l}-0.61 \\
(-2.01)^{* *}\end{array}$ & $\begin{array}{l}-0.16 \\
(-0.81)\end{array}$ & $\begin{array}{l}-0.20 \\
(-1.03)\end{array}$ \\
\hline Analyst & $\begin{array}{l}0.37 \\
(3.04) * * *\end{array}$ & $\begin{array}{l}0.40 \\
(3.33) * * *\end{array}$ & $\begin{array}{c}-0.02 \\
(-0.23)\end{array}$ & $\begin{array}{c}0.02 \\
(0.21)\end{array}$ \\
\hline
\end{tabular}


TABLE 11. (Continued)

\begin{tabular}{lcccccc}
\hline & & \multicolumn{2}{c}{ A. Capital Investment } & & \multicolumn{2}{c}{ B. Noncapital Investment } \\
\cline { 1 - 3 } \multicolumn{1}{c}{ Variables } & & Model 1 & Model 2 & & Model 3 & Model 4 \\
\cline { 1 - 1 } \cline { 6 - 7 } Year/Industry FE & & Yes & Yes & & Yes & Yes \\
Firm cluster & & Yes & Yes & & Yes & Yes \\
$\mathrm{N}$ & 2810 & 2810 & & 1827 & 1827 \\
$\mathrm{R}^{2}$ & 0.302 & 0.295 & & 0.250 & 0.210 \\
\hline
\end{tabular}

Note: This table presents the regression analyses of firm characteristics and CEO optimism (as in table 5) by different measures of investment ratios. Panel A reports the results of the capital investment and Panel B reports the results of non-capital investment. All variables are as defined in the table 1 and winsorized at the 5th and 95th percentiles. The model includes year and industry fixed-effects based on the Fama-French 49 industry classifications. t-Statistics are presented in parenthesis below the coefficients and are corrected for heteroskedasticity, and cross-sectional and time-series correlation using a one-way cluster at the firm level. The number of observations varies because of data unavailability. $* * *, * *$, and $*$ represent the $1 \%, 5 \%$, and $10 \%$ significance levels, respectively.

constraints and then rank firms by level of constraint, from the smallest to largest. We define the lowest $30 \%$ firms based on the Kaplan-Zingales index as the least financially constrained firms and the highest $30 \%$ of firms as the most financially constrained firms. The most_constrained dummy and least_constrained dummy are included in the regression model to investigate how CEO optimism affects investment under financial constraints. The results of Models 1 and 2 in panel A of table 13 indicate that CEOs with high optimism (HighOpti) will tend to invest more than those with less optimism, which is consistent with our prediction. We observe that the coefficient of most_constrained is significantly negative at the 5\% level. As expected, highly constrained firms will spend less on capital expenditure. The interaction term HighOpti*most_constrained is also significantly positive at the $5 \%$ level, which indicates that a highly optimistic CEO is more willing to increase capital expenditure even when the firm is financially constrained. This finding is consistent with our conjecture that an optimism CEO of financially constrained firms are still willing to invest because they may overestimate the payoff of projects and underestimate the risks.

Models 3 and 4 in panel A report the results of the investment level for firms with low optimism CEOs and with the least financial constraints. We find that firms with the least financial constraints will tend to invest more than firms with more financial constraints. 
TABLE 12. Relationship between CEO Optimism, Investment, and Firm Value

\begin{tabular}{|c|c|c|}
\hline Variables & Model 1 & Model 2 \\
\hline Intercept & $\begin{array}{l}2.57 \\
(4.72)^{* * *}\end{array}$ & $\begin{array}{l}3.29 \\
(6.12)^{* * * *}\end{array}$ \\
\hline investment (HighOpti) & $\begin{array}{l}0.06 \\
(5.03)^{* * *}\end{array}$ & \\
\hline invest̂ment (LowOpti) & & $\begin{array}{l}-0.04 \\
(-1.12)\end{array}$ \\
\hline Firm size & $\begin{array}{l}-0.33 \\
(-7.05)^{* * *}\end{array}$ & $\begin{array}{l}-0.39 \\
(-8.58) * * *\end{array}$ \\
\hline Capex/Sale & $\begin{array}{l}-0.00 \\
(-0.76)\end{array}$ & $\begin{array}{l}-0.00 \\
(-0.14)\end{array}$ \\
\hline Profitability & $\begin{array}{l}0.06 \\
(9.02)^{* * *}\end{array}$ & $\begin{array}{l}0.07 \\
(9.53)^{* * * *}\end{array}$ \\
\hline Return & $\begin{array}{c}0.01 \\
(11.41)^{* * *}\end{array}$ & $\begin{array}{c}0.01 \\
(13.10)^{* * * *}\end{array}$ \\
\hline Ind. leverage & $\begin{array}{l}-0.02 \\
(-2.99) * * *\end{array}$ & $\begin{array}{l}-0.03 \\
(-3.48) * * *\end{array}$ \\
\hline CEO ownership & $\begin{array}{c}0.01 \\
(0.72)\end{array}$ & $\begin{array}{c}0.01 \\
(0.87)\end{array}$ \\
\hline CEO-equity-based pay & $\begin{array}{l}0.01 \\
(7.20)^{* * *}\end{array}$ & $\begin{array}{l}0.01 \\
(7.83) * * *\end{array}$ \\
\hline GIM index & $\begin{array}{l}-0.00 \\
(-0.20)\end{array}$ & $\begin{array}{l}-0.01 \\
(-0.66)\end{array}$ \\
\hline Pension Own & $\begin{array}{l}-0.05 \\
(-2.28)^{* *}\end{array}$ & $\begin{array}{l}-0.06 \\
(-2.73) * * *\end{array}$ \\
\hline Analyst & $\begin{array}{l}0.08 \\
(8.94)^{* * *}\end{array}$ & $\begin{array}{c}0.09 \\
(10.04)^{* * * *}\end{array}$ \\
\hline Year/Industry FE & Yes & Yes \\
\hline Firm cluster & Yes & Yes \\
\hline $\mathrm{N}$ & 2807 & 2807 \\
\hline $\mathrm{R}^{2}$ & 0.531 & 0.539 \\
\hline
\end{tabular}

Note: This table presents how CEO optimism influences the investment and the resulting firm value. We employ the two-stage least square (2SLS) method by first estimating equation (1) to obtain the fitted values of investment. We then use these fitted values from the investment equation to estimate the following model:

$$
\text { Value }_{i t}=\beta_{0}+\beta_{1} \text { investment }_{i t}+\beta_{i} \sum \text { controls }_{i t}+\varepsilon_{i t}
$$

Model 1 reports the results for the firms with high optimism CEOs and model 2 reports the results for the firms with low optimism CEOs. All variables are as defined in the table 1 and winsorized at the 5 th and 95 th percentiles. The model includes year and industry fixed-effects based on the Fama-French 49 industry classifications. t-Statistics are presented in parenthesis below the coefficients and are corrected for heteroskedasticity, and cross-sectional and time-series correlation using a one-way cluster at the firm level. The number of observations varies because of data unavailability. ${ }^{* * *}, * *$, and $*$ represent the $1 \%, 5 \%$, and $10 \%$ significance levels, respectively. 
TABLE 13. Relationship between Firm Financial Constraints, Investment/Firm Value, and CEO Optimism

\begin{tabular}{|c|c|c|c|c|}
\hline \multicolumn{5}{|l|}{ A. Investment } \\
\hline Variables & Model 1 & Model 2 & Model 3 & Model 4 \\
\hline Intercept & $\begin{array}{l}10.37 \\
(7.59)^{* * * *}\end{array}$ & $\begin{array}{l}18.72 \\
(4.32) * * *\end{array}$ & $\begin{array}{l}11.67 \\
(8.58)^{* * * *}\end{array}$ & $\begin{array}{l}20.27 \\
(4.73)^{* * * *}\end{array}$ \\
\hline HighOpti & $\begin{array}{l}2.34 \\
(4.98)^{* * *}\end{array}$ & $\begin{array}{l}1.27 \\
(2.06) * *\end{array}$ & & \\
\hline most_constrained & $\begin{array}{l}-2.16 \\
(-2.11) * *\end{array}$ & $\begin{array}{l}-2.61 \\
(-2.24)^{* *}\end{array}$ & & \\
\hline HighOpti*most_constrained & $\begin{array}{l}0.25 \\
(2.54) * *\end{array}$ & $\begin{array}{l}0.69 \\
(2.21)^{* *}\end{array}$ & & \\
\hline LowOpti & & & $\begin{array}{l}-2.06 \\
(-3.88) * * *\end{array}$ & $\begin{array}{l}-1.91 \\
(-2.71)^{* * * *}\end{array}$ \\
\hline least_constrained & & & $\begin{array}{l}8.30 \\
(4.24)^{* * *}\end{array}$ & $\begin{array}{l}4.64 \\
(2.82)^{* * * *}\end{array}$ \\
\hline LowOpti*least_constrained & & & $\begin{array}{c}-1.99 \\
(-0.98)\end{array}$ & $\begin{array}{c}4.55 \\
(1.96)^{*}\end{array}$ \\
\hline Firm size & & $\begin{array}{l}-0.90 \\
(-2.41)^{* *}\end{array}$ & & $\begin{array}{l}-1.10 \\
(-2.99)^{* * * *}\end{array}$ \\
\hline$M / B$ & & $\begin{array}{l}0.41 \\
(3.25)^{* * * *}\end{array}$ & & $\begin{array}{l}0.45 \\
(3.65)^{* * * *}\end{array}$ \\
\hline Ind. leverage & & $\begin{array}{c}0.14 \\
(1.48)\end{array}$ & & $\begin{array}{c}0.15 \\
(1.55)\end{array}$ \\
\hline CF/Sale & & $\begin{array}{c}0.04 \\
(1.90)^{*}\end{array}$ & & $\begin{array}{l}0.05 \\
(2.28) * *\end{array}$ \\
\hline Operating Cycle & & $\begin{array}{c}-0.87 \\
(-0.56)\end{array}$ & & $\begin{array}{c}-0.88 \\
(-0.57)\end{array}$ \\
\hline Dividend & & $\begin{array}{l}-2.74 \\
(-3.48) * * *\end{array}$ & & $\begin{array}{l}-2.65 \\
(-3.38) * * * *\end{array}$ \\
\hline Return & & $\begin{array}{c}0.01 \\
(1.22)\end{array}$ & & $\begin{array}{c}0.01 \\
(1.05)\end{array}$ \\
\hline Slack & & $\begin{array}{l}-0.01 \\
(-5.65)^{* * * *}\end{array}$ & & $\begin{array}{l}-0.01 \\
(-5.61)^{* * * *}\end{array}$ \\
\hline CEO ownership & & $\begin{array}{c}0.07 \\
(1.01)\end{array}$ & & $\begin{array}{c}0.10 \\
(1.32)\end{array}$ \\
\hline CEO-equity-based pay & & $\begin{array}{c}0.02 \\
(1.49)\end{array}$ & & $\begin{array}{c}0.02 \\
(1.71)^{*}\end{array}$ \\
\hline GIM index & & $\begin{array}{c}-0.03 \\
(-0.23)\end{array}$ & & $\begin{array}{l}-0.05 \\
(-0.40)\end{array}$ \\
\hline Pension Own & & $\begin{array}{c}-0.15 \\
(-0.90)\end{array}$ & & $\begin{array}{l}-0.11 \\
(-0.66)\end{array}$ \\
\hline Analyst & & $\begin{array}{c}0.08 \\
(1.12)\end{array}$ & & $\begin{array}{c}0.10 \\
(1.30)\end{array}$ \\
\hline
\end{tabular}

( Continued) 
TABLE 13. (Continued)

\begin{tabular}{|c|c|c|c|c|}
\hline \multicolumn{5}{|l|}{ A. Investment } \\
\hline Variables & Model 1 & Model 2 & Model 3 & Model 4 \\
\hline Year/Industry FE & Yes & Yes & Yes & Yes \\
\hline Firm cluster & Yes & Yes & Yes & Yes \\
\hline $\mathrm{N}$ & 7741 & 2812 & 7741 & 2812 \\
\hline $\mathrm{R}^{2}$ & 0.173 & 0.194 & 0.169 & 0.196 \\
\hline \multicolumn{5}{|l|}{ B. Firm Value } \\
\hline Intercept & $\begin{array}{c}1.69 \\
(10.45)^{* * * *}\end{array}$ & $\begin{array}{l}2.08 \\
(5.20)^{* * *}\end{array}$ & $\begin{array}{c}1.93 \\
(11.69)^{* * *}\end{array}$ & $\begin{array}{l}2.19 \\
(5.43)^{* * * *}\end{array}$ \\
\hline HighOpti & $\begin{array}{c}0.50 \\
(8.88) * * *\end{array}$ & $\begin{array}{l}0.31 \\
(4.76) * * *\end{array}$ & & \\
\hline most_constrained & $\begin{array}{l}-0.78 \\
(-9.88) * * *\end{array}$ & $\begin{array}{l}-0.05 \\
(-1.94) *\end{array}$ & & \\
\hline HighOpti*most_constrained & $\begin{array}{l}0.13 \\
(3.20)^{* * * *}\end{array}$ & $\begin{array}{l}0.18 \\
(3.39)^{* * * *}\end{array}$ & & \\
\hline LowOpti & & & $\begin{array}{l}-0.41 \\
(-6.40) * * *\end{array}$ & $\begin{array}{c}-0.07 \\
(-1.21)\end{array}$ \\
\hline least_constrained & & & $\begin{array}{l}0.55 \\
(3.03)^{* * *}\end{array}$ & $\begin{array}{c}0.35 \\
(1.71)^{*}\end{array}$ \\
\hline LowOpti*least_constrained & & & $\begin{array}{c}1.10 \\
(0.98)\end{array}$ & $\begin{array}{l}-0.47 \\
(-1.57)\end{array}$ \\
\hline Firm size & & $\begin{array}{l}-0.30 \\
(-8.25) * * *\end{array}$ & & $\begin{array}{l}-0.29 \\
(-7.94) * * *\end{array}$ \\
\hline Capex/Sale & & $\begin{array}{l}-0.00 \\
(-1.18)\end{array}$ & & $\begin{array}{c}-0.00 \\
(-0.73)\end{array}$ \\
\hline Profitability & & $\begin{array}{l}0.06 \\
(9.09) * * *\end{array}$ & & $\begin{array}{l}0.06 \\
(9.50)^{* * * *}\end{array}$ \\
\hline Return & & $\begin{array}{c}0.01 \\
(13.08) * * *\end{array}$ & & $\begin{array}{c}0.01 \\
(13.00)^{* * * *}\end{array}$ \\
\hline Ind. leverage & & $\begin{array}{l}-0.02 \\
(-3.04) * * *\end{array}$ & & $\begin{array}{l}-0.02 \\
(-3.17) * * *\end{array}$ \\
\hline CEO ownership & & $\begin{array}{c}0.00 \\
(0.28)\end{array}$ & & $\begin{array}{c}0.01 \\
(0.51)\end{array}$ \\
\hline CEO-equity-based pay & & $\begin{array}{l}0.01 \\
(7.62) * * *\end{array}$ & & $\begin{array}{l}0.01 \\
(7.68) * * *\end{array}$ \\
\hline GIM index & & $\begin{array}{c}0.00 \\
(0.31)\end{array}$ & & $\begin{array}{l}-0.00 \\
(-0.00)\end{array}$ \\
\hline Pension Own & & $\begin{array}{l}-0.04 \\
(-1.92)^{*}\end{array}$ & & $\begin{array}{l}-0.05 \\
(-2.69) * * *\end{array}$ \\
\hline Analyst & & $\begin{array}{c}0.08 \\
(10.91)^{* * *}\end{array}$ & & $\begin{array}{c}0.08 \\
(10.97)^{* * * *}\end{array}$ \\
\hline
\end{tabular}

( Continued) 
TABLE 13. (Continued)

B. Firm Value

\begin{tabular}{lcccc}
\multicolumn{1}{c}{ Variables } & Model 1 & Model 2 & Model 3 & Model 4 \\
\hline Year/Industry FE & Yes & Yes & Yes & Yes \\
Firm cluster & Yes & Yes & Yes & Yes \\
$\mathrm{N}$ & 7042 & 2901 & 7042 & 2901 \\
$\mathrm{R}^{2}$ & 0.279 & 0.541 & 0.258 & 0.533 \\
\hline
\end{tabular}

Note: This table presents the OLS regression estimates of firm financial constraints and CEO optimism on investment (Panel A) and firm value (Panel B). Models 1 and 2 investigate whether high optimism CEOs affect investment under financial constraints. Models 3 and 4 test whether low optimism CEOs increase investment for firms with fewer financial constraints. All variables are as defined in the table 1 and winsorized at the 5th and 95th percentiles. The model includes year and industry fixed-effects based on the Fama-French 49 industry classifications. t-Statistics are presented in parenthesis below the coefficients and are corrected for heteroskedasticity, and cross-sectional and time-series correlation using a one-way cluster at the firm level. The number of observations varies because of data unavailability. $* * *, * *$, and $*$ represent the $1 \%, 5 \%$, and $10 \%$ significance levels, respectively.

However, we found no significant evidence showing that low optimism CEOs in less financially constrained firms will decrease firm investment. The general results from Panel A of table 13 indicate that high optimism CEOs tend to increase their capital expenditure, but this tendency still exists when firms face high financial constraints, while low optimism CEOs are not observed to significantly affect firm investment level even when firms are less financially constrained.

Panel B of table 13 also reports the association among firm valuation, CEO optimism and firm financial constraints. The results of table 13 report that the coefficient of HighOpti is significantly positive at the $1 \%$ level, indicating that high-optimism CEOs contribute to higher firm valuation. If firms are financially constrained, they have significantly lower firm value than those without financial constraints. Interestingly, we find that CEO optimism significantly increases firm valuation when firms are financially constrained. This corresponds to the findings in Panel A of table 13 and indicates that an optimistic CEO tends to increase firm investment even under financial constraints, which may lead to an increase in firm valuation. In addition, we also find that firms with the least financial constraints tend to have higher firm values than firms with high financial constraints. However, there is no significant evidence showing that low optimism CEOs in less financially constrained firms will increase firm value. 


\section{Discussion and Conclusions}

Studies suggest that corporate investment is affected by managerial personal preferences and behavior biases, but these studies do not directly address how managerial optimism affects a firm's investment efficiency, or whether managerial optimism helps to improve corporate investment efficiency. In this study, we focus on how managerial optimism affects a firm's investment efficiency and its association to firm valuation. We first measure the level of CEO optimism (Campbell et al., 2011) and identify firms that are prone to under-invest or over-invest (Biddle et al., 2009). We find that almost $40 \%$ of CEOs are optimistic in our sample, which is consistent with prior studies (e.g., Glaser 2008). Firms with a highly optimistic CEO will invest more than firms whose CEOs have lower levels of optimism. In addition, our findings indicate that an under-invested firm with a CEO that has a high level of managerial optimism improves the firm's investment efficiency by reducing the amount of underinvestment, thereby increasing firm value, consistent with our hypotheses. However, when firms tend to over-invest, our results do not provide sufficient evidence to support the other hypotheses. An over-invested firm that has a low optimism CEO is not found to effectively improve the firm's investment efficiency and increase firm value by reducing the level of overinvestment. Our main empirical results still hold after several tests of robustness. We also find that an optimistic CEO tends to increase firm investment even under financial constraints and also leads to an increase in firm valuation.

Accepted by: Prof. H. Shefrin, Guest Editor, January 2013

Prof. P. Theodossiou, Editor-in-Chief, January 2013

\section{References}

Amihud, Y., and Lev, B. 1981. Risk Reduction as a Managerial Motive for Conglomerate Mergers. Bell Journal of Economics 12: 605-617.

Baek, J. S.; Kang, J. K.; and Park, K. S. 2004. Corporate Governance and Firm Value: Evidence from the Korean Financial Crisis. Journal of Financial Economics 71: 265-313.

Baker, M.; Stein, J.; and Wurgler, J. 2003. When Does the Market Matter? Stock Prices and the Investment of Equity-Dependent Firms. Quarterly Journal of Economics 118: 969-1005.

Barberis, N., and Thaler, R. 2003. A Survey of Behavioral Finance. In Handbook of the Economics of Finance, edited by G.M. Constantinides, M. Harris and R. Stulz, Elsevier 2003: 1053-1128. 
Barberis, N.; Shleifer, A.; and Vishny, R. 1998. A Model of Investor Sentiment. Journal of Financial Economics 49: 307-343.

Barros, L., and Silveira, A. 2009. Overconfidence, Managerial Optimism, and the Determinants of Capital Structure. Brazilian Review of Finance 6(3), 293-335.

Ben-David, I.T.; Graham, J. R.; and Harvey, C. R., "Managerial Miscalibration." SSRN, Working Paper No.1640552.

Bertrand, M., and Mullainathan, S. 2003. Enjoying the Quiet Life? Corporate Governance and Managerial Preferences. Journal of Political Economy 111: 1043-1075.

Biddle, G., and Hilary, G. 2006. Accounting Quality and Firm-Level Capital Investment. The Accounting Review 81: 963-982.

Biddle, G.; Hilary, G.; and Verdi, R. 2009. How Does Financial Reporting Quality Relate to Investment Efficiency? Journal of Accounting and Economics 48: 112-131.

Campbell, T. C.; Gallmeyer, M.; Johnson, S. A.; Rutherford, J.; and Stanley, B. W. 2011. CEO Optimism and Forced Turnover. Journal of Financial Economics 101: 695-712.

Cremers, K., and Nair, V. 2005. Governance Mechanisms and Equity Prices. The Journal of Finance 60: 2859-2894.

Daniel, K.; Hirshleifer, D.; and Subrahmanyam, A. 1998. Investor Psychology and Security Market Under- and Over-reactions. The Journal of Finance 53: 1839-1885.

Fama, E. F., and French, K. R. 1997: Industry Costs of Equity, Journal of Financial Economics 43: 153-193.

Gervais, S.; Heaton, J.; and Odean, T. 2002. the Positive Role of Overconfidence and Optimism In Investment Policy. Working paper, University of California, Berkeley.

Glaser, M.; Schafers, P.; and Weber, M. 2008. Managerial Optimism and Corporate Investment: Is the CEO Alone Responsible For the Relation? AFA 2008 New Orleans Meetings Paper. Available at SSRN: http://ssrn.com/abstract=967649.

Goel, A. M., and Thakor, A. V. 2008. Overconfidence, CEO Selection, and Corporate Governance. The Journal of Finance 63: 2737-2784.

Gompers, P.; Ishii, J.; and Metrick, A. 2003. Corporate Governance and Equity Prices. Quarterly Journal of Economics 118: 107-155.

Hackbarth, D. 2008. Managerial Traits and Capital Structure Decisions. Journal of Financial and Quantitative Analysis 43: 843-882.

Heaton, J. B. 2002. Managerial Optimism and Corporate Finance. Financial Management 31: 33-45.

Hirshleifer, D. A.; Teoh, S. H.; and Low, A. 2012. Are Overconfident CEOs Better Innovators?. The Journal of Finance, 67: 1457-1498.

Hubbard, R.G. 1998. Capital Market Imperfections and Investment. Journal of Economic Literature 36: 193-225.

Jensen, M. 1986. Agency Costs of Free Cash Flow, Corporate Finance, and Takeovers. American Economic Review 76: 323-329. 
Jensen, M. 1993. the Modern Industrial Revolution, Exit, and the Failure of Internal Control Systems. The Journal of Finance 48: 831-880.

Kaplan, S. N., and Zingales, L. 1997. Do Investment-Cash Flow Sensitivities Provide Useful Measures of Financing Constraints. Quarterly Journal of Economics, 112(1), 169-215.

Lamont, O. 2000. Investment Plans and Stock Returns. The Journal of Finance, 55: 2719-2745.

Lang, L.; Ofek, E.; and Stulz, R. 1996: Leverage, Investment, and Firm Growth, Journal of Financial Economics, 40: 1996: 3-29.

Lemmon, M., and Lins, K. 2003. Ownership Structure, Corporate Governance, and Firm Value: Evidence from the East Asian Financial Crisis. The Journal of Finance, 58: 1445-1468.

Lin, Y. H.; Hu, S. Y.; and Chen, M. S. 2005. Managerial Optimism and Corporate Investment: Some Empirical Evidence from Taiwan. Pacific-Basin Finance Journal 13: 523-546.

Lin, Y. H.; Hu, S. Y.; and Chen, M. S. 2008. Testing Pecking Order Prediction from the Viewpoint of Managerial Optimism: Some Empirical Evidence from Taiwan, Pacific-Basin Finance Journal 16: 160-181.

Malmendier, U., and Tate, G. 2005a, CEO Overconfidence and Corporate Investment. Journal of Finance 60: 2661-2700.

Malmendier, U., and Tate, G. 2005b. Does Overconfidence Affect Corporate Investment? CEO Measures Revisited, European Financial Management 11: 649-659.

Malmendier, U., and Tate, G. 2008. Who Makes Acquisitions? CEO Overconfidence and the Market'S Reaction. Journal of Financial Economics 89: 20-43.

Myers, S. 1977. Determinants of Corporate Borrowing, Journal of Financial Economics 5: 147-175.

Myers, S. 1984. the Capital Structure Puzzl, Journal of Finance 39: 575-592.

Myers, S., and Majluf, N. 1984. Corporate Financing and Investment Decisions When Firms Have Information That Investors Do Not Have. Journal of Financial Economics 13: 187-221.

Opler, T.; Pinkowitz, L.; Stulz, R.; and Williamson, R. 1999. The Determinants and Implications of Corporate Cash Holdings. Journal of Financial Economics 52: 3-46.

Petersen, M. 2009. Estimating Standard Errors In Finance Panel Data Sets: Comparing Approaches. Review of Financial Studies 22: 435-480.

Shefrin, H. 2001. Behavioral Corporate Finance. Journal of Applied Corporate Finance 14: 113-124.

Shleifer, A., and Vishny, R. 1989. Management Entrenchment: The Case of Manager-Specific Investments. Journal of Financial Economics 25: 123-139.

Stein, J. C. 2003. Agency, Information and Corporate Investment. In Handbook of the Economics of Finance, edited by G.M. Constantinides, M. Harris and R. Stulz, Elsevier 2003: 111-165. 